\title{
Kaybedilen Yaşam Yılını Etkileyen Risk Faktörlerinin DEMATEL Yöntemi Kullanılarak İncelenmesi
}

\author{
GIZZM ZEVDE AYDIN* \\ gizemzevde.aydin@omu.edu.tr \\ ORCID-ID: 0000-0002-8249-6788
}

\author{
AHMET SERHAT ULUDAĞ ${ }^{* *}$ \\ serhat.uludag@omu.edu.tr \\ ORCID-ID: 0000-0002-0058-2384
}

Öz: Bu çalışmada The Decision Making Trial and Evaluation Laboratory (DEMATEL) yöntemi vasıtasıyla kaybedilen yaşam yılları (YLL) üzerinde etkili olan 19 risk faktörü arasındaki neden sonuç ilişkisi araştırılmış ve risk faktörlerinin göreceli ağırlıkları hesaplanmıştır. Bu yolla, sağhlklı geçirilen yaşam yılında kayıplara neden olması muhtemel risklerin bertaraf edilerek kıt olan kaynakların etkin kullanımının ve uygulamaya konulacak olası tedbirlerin etkililiğinin sağlanması amaçlanmıştır. Elde edilen bulgulara göre 19 risk faktörü; 10'u etkileyen, 9'u ise etkilenen olmak üzere iki gruba ayrılmıştır. Etkileyen faktörler içerisinde alkol başta olmak üzere bağımlılığa neden olan maddelerin kullanımı, etkilenen risk faktörleri ve dolayısıyla kaybedilen yaşam yıl üzerinde en fazla etkiye neden olan faktörler olarak belirlenmiştir. Etkileyen grubunda yer alan 10 risk faktörünün ortaya çıkma olasıliğı; uygulamaya konulacak olan sağlıkla ilgili ve idari tedbirler, bilinçlendirme ve küçük yaşta eğitim yoluyla büyük ölçüde bertaraf edilebilir.

Anahtar Kelimeler: Karar verme, Karar verme teknikleri, Toplum sağhl̆̆ı, Yaşam beklentisi.

\section{Giriş}

Gelişen teknolojiyle birlikte yaşam tarzının, yeme-içme alışkanlıklarının değişmesi, artan iş temposunun neden olduğu yoğun stres, bağımlılık yapıcı maddelerin kullanımının yaygınlaşması ve kullanım yaşının düşmesi, her geçen gün artan şehirleşme, çevre kirliliği vb. pek çok risk faktörü bireyin sağlı̆̆ını olumsuz yönde etkilemekte ve insan ömrünü kısaltmaktadır. Sağlıklı geçirilen yaşam yıllarında kayba ve hatta ölüme neden olan risk faktörlerinden başlıcaları T.C. Sağlık Bakanlığg 2017 yılı sağlık istatistikleri yıllığına göre; "yüksek beden kitle indeksi, aile içi şiddet, alkol kullanımı, beslenmeyle ilgili riskler, böbrek fonksiyon bozukluğu, çevreyle ilgili diğer riskler, çocuk ve annede malnütrisyon, çocuklukta kötü muameleye maruz kalma, düşük kemik mineral yoğunluğu, güvenli olmayan su, sanitasyon ve el yıkama, hava kirliliği, korunmasız cinsel ilişki, madde kullanımı, mesleki riskler, tütün kullanımı (aktif ve pasif), yetersiz fiziksel aktivite, yüksek açlık kan şekeri, yüksek

\footnotetext{
* Arş. Gör., Ondokuz Mayıs Üniversitesi, Sağlık Bilimleri Fakültesi, Sağlık Yönetimi Bölümü

** Dr. Öğr. Üyesi, Ondokuz Mayıs Üniversitesi, İktisadi ve İdari Bilimler Fakültesi, Uluslararası Ticaret ve Lojistik Bölümü
} 
LDL kolesterol, yüksek sistolik kan basıncı" olarak ifade edilmektedir. ${ }^{1}$ Hastalık yükünün hesaplanmasında kullanılan ve erken yaşlardaki ölümler ile ölümle sonuçlanmayan ancak uzun dönemli işlev kaybına yol açan hastalıklar ve yaralanmalar nedeniyle kaybedilen yılları sayan, mutlak bir sağlık kaybı olarak ifade edilen DALY ölçütü, erken ölüm sebebiyle kaybedilen yaşam yılı (YLL) ve ölüme yol açmayan ancak ideal olmayan sağlık koşullarında yaşanılan yılların (YLD) toplamından oluşmaktadır. ${ }^{2}$ Kısaca erken ölüm nedeniyle kaybedilen yaşam yılları için YLL; ölümle sonuçlanmayan fakat yaşam kalitesini düşüren sağllk sorunlarıyla geçirilen yaşam yılları için ise, YLD ölçütü kullanılmaktadır. Bu iki ölçütü bir araya getiren DALY ise sağlık kaybı için kullanılmakta olup; 1 DALY, sağlıklı geçirilen 1 yaşam yılının yitirilmesi anlamına gelmektedir. ${ }^{3}$

Sağlık Bakanlı̆̆ı tarafından yayınlanan istatistiklere göre, 2002 yllında Türkiye'de 100.000 kişiye düşen kaybedilen yaşam yılı toplam 17.063 iken; bu sayı, 2017 yllına gelindiğinde 11.885 ’e gerilemiştir. Cinsiyete göre 100.000 kişiye düşen kaybedilen yaşam yılı istatistikleri, kadınlarda meydana gelen düşüşün erkeklere göre daha fazla olduğunu göstermektedir. Keza, kadınlarda 2002 yılında 14.142 olan 100.000 kişiye düşen YLL, 2017 yllında 8.528'e gerilemiştir. Bununla birlikte, erkeklerde 2002 yılında 19.950 olan 100.000 kişiye düşen YLL, 2017 yllında 15.236'ya gerilemiştir. Bu gerilemede, YLL'de etkili olan risk faktörlerinin ve özellikle kadın nüfusta YLL'ye neden olan başlıca faktörlerin paylarının düşmesinin etkili olduğu söylenebilir. Yine Sağlık Bakanlığı verilerine göre, 2017 yılı ilk 10 YLL nedeni; iskemik kalp hastalığı, neonatal hastalıklar, trakea, bronş ve akciğer kanserleri, inme, konjenital doğum anomalileri, kronik obstrüktif akciğer hastalığı, trafik kazaları, kronik böbrek hastalığı, diyabet, Alzheimer ve diğer demans hastalıkları şeklinde sıralanmaktadır. 2002 yılında 1.507.528 olan toplam iskemik kalp hastalığı sayısı, 2017 yılına gelindiğinde $\% 0,016$ 'lık artışla 1.509 .976 'ya çıkmıştır. 2002 yllında 2.108 .974 olan toplam neonatal hastalık sayısı, 2017 yılında \%67,72 oranında gerileyerek 680.865 olarak kayıtlara geçmiştir. 2002 yilında 475.717 olan toplam trakea, bronş ve akciğer kanserleri sayısı, 2017 yılına gelindiğinde \%37,70'lik artışla 655.068'e yükselmiştir. Toplam inme sayısı 2002 yılında 413.194 iken; bu sayı 2017 yllına gelindiğinde \%55,60'lık artışla 642.929'a yükselmiştir. 2002 yılında toplam konjenital doğum anomalileri sayısı 919.470 iken; 2017 yılına gelindiğinde bu sayı \%50,07'lik gerilemeyle birlikte 459.075 olarak gerçekleşmiştir. Kronik obstrüktif akciğer hastalığı sayısı 2002 yılında 262.266 iken; bu sayı 2017 yılına gelindiğinde \%63,04'lük artışla 427.595 olarak gerçekleşmiştir. 2002 yılında 372.505 trafik kazası sayısı, 2017 yılına gelindiğinde \%10,03'lük artışla 409.862 olarak gerçekleşmiştir. Kronik böbrek hastalığı sayısı 2002 yılında 229.221 iken; bu sayı 2017 yılına gelindiğinde \%26,14'lük artışla 289.128 olarak kayıtlara yansımıştır. Diyabet sayısı toplamı 2002 yılında 254.821 iken; 2017 yılında bu sayı \%11'lik artışla 282.840 olarak gerçekleşmiştir. Ve son olarak alzheimer ve diğer demans hastalıkları sayısı 2002 yılında 158.090 olarak kayıtlarda yer alırken;

1 T.C. Sağlık Bakanlığı, Sağlık İstatistikleri Yıllığı 2017, Ankara: Kuban Matbaacılık, 2017, s.105.

2 T.C. Sağlık Bakanlı̆̆ı Temel Sağlık Hizmetleri Genel Müdürlüğü, Ulusal Ruh Sağllğı Eylem Planı (2011-2023), Ankara: Sağlık Bakanlı̆̆ı Yayınları, 2011, s.5.

3 T.C. Sağlık Bakanlığı, Sağlk İstatistikleri, s.109. 
bu sayı 2017 yılında \%64,04'lük artışla 259.328 olarak gerçekleşmiştir. 2002 yılından 2017 yllına ilk 10 YLL nedenindeki yüzdelik değişimlerde neonatal hastalıklardaki ve konjenital doğum anomalilerindeki ciddi düşüş; inme, kronik obstrüktif akciğer hastalığı, alzheimer ve diğer demans hastalıklarındaki önemli orandaki artış ise dikkat çekicidir. Bunun yanı sıra, seçilmiş risk faktörlerinin YLL'deki \%'lik payları dikkate alındığında; yüksek beden kitle indeksi, aile içi şiddet, alkol kullanımı, beslenmeyle ilgili riskler, böbrek fonksiyon bozukluğu, çevreyle ilgili diğer riskler, çocuk ve annede malnütrisyon, çocuklukta kötü muameleye maruz kalma, düşük kemik mineral yoğunluğu, güvenli olmayan su, sanitasyon ve el yıkama, hava kirliliği, korunmasız cinsel ilişki, madde kullanımı, mesleki riskler, tütün kullanımı (aktif ve pasif), yetersiz fiziksel aktivite, yüksek açlık kan şekeri, yüksek LDL kolesterol, yüksek sistolik kan basıncı gibi risk faktörlerinden çocuk ve annede malnütrisyon risk faktörünün YLL'deki payının 2002'de yaklaşı \%24'lük payının ciddi oranda gerileyerek 2017'de yaklaşık \%8'lerde gerçekleştiği anlaşılmaktadır. Bununla birlikte, yüksek sistolik kan basıncı, yüksek LDL kolesterol, yüksek açlık kan şekeri ve hava kirliliği gibi risk faktörlerinin YLL’deki \%'lik paylarının bir miktar arttığı da Sağlık Bakanlığı tarafından yayınlanan 2017 yılı verilerinden anlaşılmaktadır. Kaybedilen yaşam yllı üzerinde etkili olan risk faktörleri ve YLL'ye neden olan hastalıklar dikkate alındığında; Türkiye’de 2017 yllında 100.000 kişiye düşen YLL 11.885 olup; bu haliyle orta üst gelir grubu ülkelerinden, OECD ülkelerinden, üst gelir grubu ülkelerinden, $\mathrm{AB}$ ülkelerinden, DSÖ Avrupa Bölgesinden ve dünya ortalamasından daha iyi bir durumda gözükmektedir ${ }^{4}$.

$\mathrm{Bu}$ çalışmanın temel amacı, sağlıklı geçirilen bir yaşam yılının kaybında etkili olan iki temel bileşenden biri olan YLL ölçütü üzerinde etkili olan risk faktörlerinin birbirleri arasındaki ilişkileri irdelemek, bunları etkileyen ve etkilenen risk faktörleri bağlamında gruplandırmak, söz konusu risk faktörlerinin ağırlıklarını hesaplamak, hem birey hem de toplum sağlığını olumsuz etkileyebilecek risk faktörlerinin azaltılması ve hatta ortadan kaldırılabilmesi için kıt kaynakların öncelikli konulara yönlendirilmesini sağlayacak sağlık politikası önerileri sunmaktır. Bu amaç doğrultusunda ilk olarak YLL üzerinde etkili olan risk faktörlerinin neler olabileceğine ilişkin bir araştırma yapılmıştır. Seçilen risk faktörlerinde tutarlı olabilmek için T.C. Sağlık Bakanlığı tarafından yayınlanan 2017 Sağlık İstatistik Ylllığında YLL üzerinde etkili olan başlıca risk faktörleri olarak gösterilen 19 risk faktörünün analizde kullanılmasına karar verilmiştir. Söz konusu risk faktörlerinden hangilerinin etkileyen hangilerinin etkilenen olduğunun tespiti; bir diğer ifadeyle, risk faktörleri arasındaki içsel ilişkilerin ortaya çıkarılması ve göreli ağırlıklarının hesaplanabilmesi için uzman görüşüne dayanan Çok Kriterli Karar Verme (ÇKKV) yöntemlerinden biri olan The Decision Making Trial and Evaluation Laboratory (DEMATEL) yöntemi kullanılmıştır.

\section{Kaybedilen Yaşam Yılında Etkili Olan Bazı Risk Faktörleri}

Kaybedilen yaşam yılı üzerinde etkili olan başlıca risk faktörleri arasında yer alan bağımlılıklar birey ve toplum sağlığı üzerinde olumsuz etkileri ve gelecek nesilleri 
etkileme özelliği nedeniyle üzerinde önemle durulması gereken bir husustur. Tütün ve tütün mamulleri kadar kullanımı yaygın olmasa da alkol tüketiminin kanser, hipertansiyon, karaciğer sirozu, pankreas iltihabı, alkol bağımlılığı, şiddet, kaza ve yaralanma gibi olumsuz sonuçları beraberinde getirdiği görülmektedir. ${ }^{5}$ Tütün ve tütün mamullerini kullanma, yaygın bir bağımlılık çeşidi olmasının yanı sıra tütünde ve dumanında bulunan maddelerin insan sağlı̆̆ üzerine yaptığı son derece önemli zararlar nedeniyle, tütün ve tütün mamulleri kullanımı en önemli halk sağlığı sorunlarından biridir. ${ }^{6}$ Dünya Sağlık Örgütü (DSÖ) verilerine göre her yıl 8 milyondan fazla kişi tütün ve tütün mamulleri kullanımından kaynaklı olarak hayatını kaybetmektedir. Ölümlerin büyük çoğunluğunun gelir seviyesinin düşük olduğu ve tütüne dayalı endüstrinin geliştiği coğrafyalarda meydana gelmesi $\mathrm{de}^{7}$, gelişmişlik ve tütün kullanımı arasındaki ters orantılı ilişkiye işaret etmektedir. Tütün kullanımı, bağımlılığa neden olmanın yanı sıra pek çok hayati riske neden olabilecek hastalığa da zemin hazırlamaktadır. Bununla birlikte, tütün ve tütün mamullerini kullanmaya başlama zamanı ile tütün kullanımından kaynaklı gerçekleşen ölüm zamanı arasındaki süre nispeten uzundur. ${ }^{8}$ Tütün ve tütün mamullerinin kullanımı, sadece kullananları değil aynı zamanda bu ürünlerin dumanına maruz kalan kişileri de olumsuz etkilemektedir. Günümüzde pasif içicilik olarak ifade edilen bu durumun önüne geçilebilmesi için son yıllarda getirilen yasal kısıtlamalar memnuniyet vericidir.

Kaybedilen yaşam yılları üzerinde etkili olan bir diğer risk faktörü obezite, sağlığ olumsuz etkileyecek seviyelerdeki yağ birikimi olarak tanımlanmaktadır. Bireye obezite tanısının koyulabilmesinde beden kitle indeksi yaygın olarak kullanılmaktadır. Beden kitle indeksinin belirlenmiş olan standartlar dışına çıkması, başta kalp rahatsızlıkları olmak üzere, diyabet, kas ve iskelet sistemi rahatsızlıkları ile bazı kanser türlerinin ortaya çıkmasına neden olabilmektedir. ${ }^{9}$ Beden kitle indeksi (BKİ), kiloya ağırlık vermek için boyun karesini kullanır. ${ }^{10}$ Modern yaşamın beraberinde getirdiği obezite, insan sağlı̆̆ını olumsuz etkileyebilecek ciddi sağlık sorunlarının da ortaya çıkmasına neden olabilmektedir.

Olumsuz yaşam koşulları bireylerin yeterli düzeyde ve dengeli beslenmesini engelleyebilmektedir. Bu durum literatürde malnütrisyon olarak tanımlanmaktadır. ${ }^{11}$ Alınan besinlerin nitelik ve/veya nicelik bakımından yetersiz oluşu nedeniyle ortaya

5 Jürgen Rehm, Jayadeep Patra ve Svetlana Popova, "Alcohol-Attributable Mortality and Potential Years of Life Lost in Canada 2001: Implications for Prevention and Policy”, Addiction, 101 (2006), s.376; Jürgen, Rehm vd., "The Relationship of Average Volume of Alcohol Consumption and Patterns of Drinking to Burden of Disease", Addiction, 98 (2003), s.1212.

6 Özlem Örsal, "Sağlık Yüksekokulu Öğrencilerinin Tütün ve Tütün Mamulleri Kullanma Alıșkanlıkları Üzerine Kesitsel Bir Çalışma”, Turkish Journal of Research and Development in Nursing, 11/3 (2009), s.31.

7 “Health-Topics / Tobacco", erişim 12 Aralık, 2019, https://www.who.int/health-topics/tobacco.

8 Celal Karlıkaya vd., "Tütün Kontrolü”, Toraks dergisi, 7/1 (2006), s.51.

9 “Obezite ve Aşırı Kilo”, erişim 12 Aralık, 2019, https://www.who.int/en/news-room/fact-sheets/detail/obesityand-overweight.

10 Altan Onat, “Türkiye’de Obezitenin Kardiyovasküler Hastalıklara Etkisi”, Türk Kardiyoloji Derneği Arşivi, 31/5 (2003), s.280.

11 Sabahat Tezcan, Ayşegül Esin Ertan ve Dilek Aslan, "Beş Yaş Altı Çocuklarda Malnütrisyon Durumunun Değerlendirilmesi”, Türkiye Klinikleri Tip Bilimleri, 23/5 (2003), s.420. 
çıkan olumsuz tabloyu tanımlayan malnütrisyon ${ }^{12}$, yetersiz beslenme, mikro besin eksikliği ve obeziteye götüren aşırı beslenme şeklinde incelenmektedir ${ }^{13}$. Yeni doğanlar, erken çocukluk dönemindekiler, adolesanlar, hamile ve emziren kadınlar, yaşlılar, vejetaryen diyet uygulayanlar, kronik hastalığ bulunan bireyler, alkol ve ilaç bağımlıları malnütrisyon risk grubunda yer almaktadır. ${ }^{14}$ Olumsuz etkileri olabilen malnütrisyon çocuk gelişimi açısından ihmal edilmemesi gereken bir risk faktörüdür.

Bir diğer risk faktörü olan sanitasyon, katı ve hayvansal atıkların çevre ve insan sağlığına zarar vermeyecek şekilde bertaraf edilmesi ve hijyenik bir ortamın sağlanması anlamına gelmektedir. Yeterli sanitasyon, iyi hijyen ve güvenli su, sağlık, sosyal ve ekonomik gelişim için oldukça önemlidir. ${ }^{15}$ İçinde bulunduğumuz çağda, temiz suya erişim ve sanitasyon yoksunluğu ile ilişkili hastalıklar hala önemli halk sağlığı sorunları arasında yer almaktadırlar. ${ }^{16}$ Sanitasyonun yetersiz olması, başta kolera, tifo ve dizanteri gibi bulaşıcı hastalıklara neden olduğu gibi zihinsel bazı olumsuzlukların da ortaya çıkmasına neden olabilmektedir. ${ }^{17}$

Kaybedilen yasam yılını etkileyen bir diğer risk faktörü, korunmasız cinsel ilişkidir. Korunmasız cinsel ilişki özellikle, cinsel yolla bulaşan hastalıklar ve istenmeyen gebelikler için risk faktörüdür. ${ }^{18}$ Pek çok farklı bakteri, virüs ve parazitin bulaşmasına neden olmaktadır. Bunlardan bazıları doğum sırasında anneden çocuğa bulaşarak gelecek nesilleri de olumsuz etkileyebilmektedir. ${ }^{19}$ Korunmasız cinsel ilişkinin getirdiği riskler hakkında temel ve doğru bilgiye erişim cinsel yolla bulaşan hastalıkların önüne geçilebilmesi için önem arz etmektedir.

Artan sanayileşme, şehirleşme, trafik yoğunluğu, fosil yakıtlarla ısınma gibi nedenlerden ötürü hava kirliliği günümüzde bazı coğrafyalarda insan sağlığını olumsuz etkileyecek boyutlara ulaşmış vaziyettedir. Konutlar ve sanayi tesisleri gibi sabit emisyon kaynaklarının yanı sıra motorlu taşıtların kullanımından kaynaklanan egzoz kirliliği de havanın kirlenmesine aynı derecede katkıda bulunmaktadır ${ }^{20}$. Hava kirliliğini önlemeye yönelik dünya genelinde yürütülen çalışmalara rağmen, farklı coğrafyalarda hava kirliliği seviyesi sürekli yüksek seyretmektedir. ${ }^{21}$ Hava kirliliği ve çevresel asbeste maruz kalmak akciğer sağlını olumsuz etkileyebilmektedir. ${ }^{22}$

12 Yves Guigoz, “The Mini Nutritional Assessment Review of the Literature - What Does it Tell Us?”, The Journal of Nutrition, Health and Aging, 10 (2006), s.466.

13 "Yetersiz Beslenme", erişim 12 Aralık, 2019, https://www.who.int/topics/malnutrition/en/.

14 Tezcan, Esin Ertan ve Dilek "Beş Yaş Altı", s.420.

15 Mara Duncan vd., "Sanitation and Health", PLoS Medicine, 7/11 (2010), s.1.

16 Hutton Guy ve Haller Laurence, Evaluation of the Costs and Benefits of Water and Sanitation Improvements at the Global Level, Geneva: World Health Organization, 2004, s.7.

17 “Sanitasyon", erişim 12 Aralık, 2019, https://www.who.int/topics/sanitation/en/.

18 Saniye Korkmaz Çetin vd., "Erkek Ergenlerde Cinsel Davranış ve Cinsel Bilgi Kaynakları: Sekiz Yıl Arayla Değerlendirme”, Türk Psikiyatri Dergisi, 19/4 (2008), s.394.

19 “Cinsel Sağlık ve Üreme Sağlığı”, erişim 12 Aralık, 2019, https://www.who.int/reproductivehealth/curablestis/en/.

20 Tolga Elbir vd., "İzmir Kent Merkezinde Karayolu Trafiğinden Kaynaklanan Hava Kirliliğinin İncelenmesi”, Dokuz Eylül Üniversitesi Mühendislik Fakültesi Fen ve Mühendislik Dergisi, 12/1 (2010), s.2.

21 “Hava Kirliliği”, erişim 12 Aralık, 2019, https://www.who.int/airpollution/events/expertconsult2019/en/. 22 Arif Çımrın vd., Türkiye’de Temel Akciğer Sağlı̆̆ı Sorunları ve Çözüm Önerileri, ed., Muzaffer Metintaş, Ankara: 
Modern hayat ve teknolojik alanda yaşanılan radikal gelişmeler, adeta, günümüz insanını daha az fiziksel hareket noktasında teşvik etmektedir. Bedensel hareketliliğin giderek azalması, pek çok farklı sağlık sorunun da ortaya çıkmasına zemin hazırlamaktadır. ${ }^{23}$ Modernleşmenin dişsal maliyetlerinden biri olan fiziksel aktive yetersizliği, tıbbi bakım masraflarını artırdığından sağlık hizmetlerinin verimliliğinin de düşmesine neden olmaktadır. ${ }^{24}$ Bu bağlamda, önleyici bakım yoluyla fiziksel hareketliliğin arttırılması, tıbbi masrafları azaltacağı gibi sağlık hizmetlerinin verimliliğin de yükselmesini olumlu katkı yapacaktır. ${ }^{25}$

Kaybedilen yaşam yılını etkileyen bir diğer risk faktörü, ailedeki bir bireyin diğer bireylerin bedensel ve/veya zihinsel sağlıklarını olumsuz yönde etkileyecek eylemlerde olarak tanımlanan aile içi şiddettir. ${ }^{26}$ Aile içi şiddet, sadece şiddete maruz kalan kişide değil; aynı zamanda, aile içi şiddetin uygulandığı ortamda yetişen çocuklarda da gelecekte ruhsal, bedensel ve/veya davranışsal bozukların görülmesine neden olmaktadır. ${ }^{27}$ Bunun yanı sıra, genetik, nörolojik ve biyolojik etkenler, bazı psikiyatrik bozukluklar, alkol ve madde kullanımı, sosyal destek yoksunluğu, işsizlik, yoksulluk ve içinde yaşanılan grubun şiddeti teşvik etmesi gibi birçok farklı faktörün aile içi şiddetin ortaya çıkmasında etkili olmaktadır. ${ }^{28}$

Yukarıda bir kısmına değinilmeye çalışılan bu tür riskler bireyin ve nihayetinde toplumun sağlığını olumsuz yönde etkilemekte ve sağlıklı geçirilen yaşam yılında kayıplara neden olmaktadır. Bahsedilen bu riskler, önleyici sağlık uygulamaları ve bilinç düzeyinin arttırılması yoluyla büyük ölçüde azaltılabilir risklerdir. Bu risklerin gerçekleşmesinden sonra katlanılacak maliyetlerin gerek birey gerek toplum açısından ne kadar büyük kayıplara neden olduğu dikkate alınacak olursa, önleyici faaliyetlerin ve bireyin bilinç düzeyinin arttırılmasının sağlayacağı kazancın önemi de daha net anlaşılabilecektir.

\section{Literatür Araştırması}

Çok Kriterli Karar Verme Yöntemlerinin sağlık bilimleriyle ilintili konulara yönelik kullanıldığı çalışmalar mevcut olmakla birlikte, bu çalışmaların sayısı sosyal ve fen bilimleri alanlarıyla karşılaştırıldığında oldukça azdır. Sosyal ve fen bilimlerinde de ÇKKV yöntemleri arasında DEMATEL yönteminin kullanıldığı çalışmaların sayısı, diğer ÇKKV yöntemlerinin tercih edildiği çalışmalara nazaran daha azdır. Bu durum DEMATEL'in sağlık bilimleri konularıyla alakalı olarak kullanıldığı çalışmaların sayısının yetersiz olmasını da etkilemektedir.

Bu bağlamda, sağlık sektörüne yönelik olarak gerçekleştirilen sınırlı sayıdaki çalış-

Sentez Matbaacılık ve Yayıncılık, 2010, s.90.

23 Sinan Bulut, "Sağlıkta Sosyal Bir Belirleyici; Fiziksel Aktivite", Turkish Bulletin of Hygiene and Experimental Biology/Türk Hijyen ve Deneysel Biyoloji, 70/4 (2013), s.207.

24 "Fiziksel Aktivite", erişim 12 Aralık, 2019, https://www.who.int/health-topics/physical-activity.

25 Bulut, "Sağlıkta Sosyal”, s.205.

26 Gülseren Ünal, “Aile İçi Şiddet”, Aile ve Toplum Eğitim - Kültür ve Araştırma Dergisi, 7/2 (2005), s.2.

27 Aslıhan Okan İbiloğlu, “Aile İçi Şiddet”, Psikiyatride Güncel Yaklaşımlar, 4/2 (2012), s.209.

28 Suna Kaymak Özmen, “Aile İçinde Öfke ve Saldırganlı̆̆ın Yansımaları”, Ankara Üniversitesi Eğitim Bilimleri Fakültesi Dergisi, 37/2 (2004), s.29. 
malardan biri İran'da gerçekleştirilmiştir. Bu çalışmada sağlı̆̆ın sosyal bileşenleri arasındaki sistematik ilişki ve söz konusu bileşenlerin önem dereceleri DEMATEL yöntemi kullanılarak araştırılmıştır. Çalışmada sosyal değişim, stres, erken yaşam, sosyal dışlanma, iş, işsizlik, sosyal destek, bağımlılık, beslenme ve ulaşım olmak üzere 10 temel bileşen kullanılmıştır. Elde edilen bulgulara göre erken yaşam en önemli etkileyen faktör iken; diğer faktörlerden de en az etkilenendir. ${ }^{29}$

Yine Kirmanşah İran'da gerçekleştirilen bir başka araştırmada, hastanelerdeki alt, orta ve üst kademe yöneticilerinde zaman yönetimini etkileyen başlica faktörler arasındaki ilişkiyi incelemek için DEMATEL yöntemi kullanılmıştır. Bu çalışmada; amaç belirleme, amaçların ve faaliyetlerin önceliklendirilmesi, planlama, yetkilendirme, iletişim ve toplantı yönetimi olmak üzere 6 değişken arasındaki neden sonuç ilişkisi irdelenmiştir. Elde edilen bulgular, amaç belirleme değişkeninin diğer değişkenleri etkileyen en önemli; toplantı yönetiminin ise diğer değişkenlerden etkilenen başlıca değişken olduğunu göstermiştir. ${ }^{30}$ DEMATEL yönteminin Bulanık MULTIMOORA ile birlikte kullanıldığı bir başka çalışmada ise, sağlık atıklarının arıtılmasına yönelik alternatif arıtma teknikleri arasından seçim yapılması amaçlanmıştır. ${ }^{31}$

Hastane tedarik zinciri performansını etkileyen gruplar arası ilişkilerin belirlenmesi ve performansı etkileyen unsurların ağırlıklarının hesaplanabilmesi için DEMATEL yönteminin kullanıldığı diğer bir çalışmada DEMATEL vasıtasıyla elde edilen ağırlıklar, geliştirilmiş ANP yöntemine aktarılarak hastane tedarik zinciri performansı değerlendirilmiştir. ${ }^{32}$

Bir başka çalışmada, sağlık sektöründeki kurumlar arasındaki bilgi paylaşımını kolaylaştıracak uzun dönemli bakım bulut sistemlerini; sistemin gelişiminde etkili olan karmaşık ve çatışan noktaları ortaya çıkarmak suretiyle değerlendirme noktasında kullanılabilecek anahtar yenilikçi ilkeleri belirleyebilmek maksadıyla TRIZ ve DEMATEL yöntemleri bir arada kullanılmıştır ${ }^{33}$. Akıllı tıbbi terminallerinin geliştirilmesi, tutundurulması için müşteri benimseme davranışında etkili anahtar faktörlerin incelenmesi ve değerlendirilmesi maksadıyla kaleme alınan başka bir çalışmada, DEMATEL, DEMATEL Tabanlı ANP ve VIKOR yöntemleri bir arada kullanılmıştır. ${ }^{34}$ Sağlık sektöründe elektronik sağlık kayıt sistemleri için kritik öneme sahip unsurları

29 Mohammadkarim Bahadori ve Ramin Ravangard, "Analysis of the Systematic Relationships among Social Determinants of Health (SDH) and Identification of Their Prioritization in Iran Using DEMATEL", Technique, Iranian Journal of Public Health, 42/12 (2013), s.1457-1464.

30 Mohammadkarim Bahadori vd., "Prioritization of Factors Affecting Time Management among Health Managers", International Journal of Travel Medicine and Global Health, 3/4 (2015), s.159-164.

$31 \mathrm{Hu}-$ Chen Liu vd., "Evaluating Health-Care Waste Treatment Technologies Using a Hybrid Multi-Criteria Decision Making Model”, Renewable and Sustainable Energy Reviews, 41 (2015), s.932-942.

32 Tuangyot Supeekit, Tuanjai Somboonwiwat ve Duangpun Kritchanchai, "DEMATEL-Modified ANP to Evaluate İnternal Hospital Supply Chain Performance”, Computers andIndustrial Engineering, 102 (2016), s.318330.

33 Dong-Shang Chang, Shu-Ming Liu ve Yi-Chun Chen, “Applying DEMATEL to Assess TRIZ's Inventive Principles for Resolving Contradictions in the Long-Term Care Cloud System”, Industrial Management and Data Systems, 117/6 (2017), s.1244-1262.

34 Yupeng Liu, Yifei Chen ve Gwo-Hshiung Tzeng, "Identification of Key Factors in Consumers' Adoption Behavior of Intelligent Medical Terminals Based on a Hybrid Modified MADM Model for Product Improvement", International Journal of Medical Informatics, 105 (2017), s.68-82. 
belirleyebilmek, bu unsurlar arası ilişkileri açığa çıkarabilmek, ağırlıklarını ve önceliklerini tespit edebilmek için gerçekleştirilen diğer bir çalışmada, yine DEMATEL, DEMATEL Tabanlı ANP ve VIKOR yöntemleri bütünleşik bir şekilde kullanılmış$\mathrm{t}^{35} \mathrm{r}^{35}$. Bütünsel hastane yönetimi için anahtar performans kriterlerini belirleyebilmek ve bu 15 kriter arasındaki neden sonuç ilişkisini inceleyebilmek maksadıyla gerçekleştirilen bir başka çalışmada ise, geliştirilmiş DEMATEL yöntemini kullanılmıştır. ${ }^{36}$

Sağlık sektöründe bir hastanenin değerlendirilmesinde olumsuz olay riskinin dikkate alınması gereken önemli bir konu olduğuna işaret edilen bir başka çalışmada, hastane sektöründe olumsuz olay riskinin değerlendirilmesine yönelik bütünleşik bir yaklaşım önerilmiş ve bu bağlamda AHP, DEMATEL ve VIKOR yöntemleri bir arada kullanılmıştır. ${ }^{37}$ Bir üniversite hastanesinin sunmuş olduğu sağlık hizmetlerinin kalitesinin değerlendirildiği diğer bir çalışmada, hizmet kalitesini etkileyen unsurları belirleyebilmek maksadıyla ilk olarak SERVQUAL analizi; ardından, bu analiz vasıtasıyla belirlenen 9 ana faktör arasındaki sebep sonuç ilişkisini ortaya çıkarabilmek ve bu faktörlerin ağırlıklarını hesaplayabilmek için ise DEMATEL yöntemi kullanılmıştır. ${ }^{38}$ DEMATEL yöntemi bir başka çalışmada, ilaç sektöründe tersine lojistik faaliyetlerinin başarıyla yerine getirilmesini etkileyecek 10 faktör arasındaki ilişki ağını irdelemek ve faktör ağıllıklarını belirleyebilmek maksadıyla kullanılmıştır. ${ }^{39}$

Fas sağlık sisteminin paydaşları için bakım kalitesinin irdelendiği bir başka çalışmada, 5W, Delphi ve DEMATEL yöntemleri bir arada kullanılırken; ${ }^{40}$ tıbbi atık bertaraf alternatiflerinin değerlendirildiği diğer bir çalı̧̧mada ise DEMATEL yöntemi, Bulanık AHP ve Bulanık ANP ile bütünleşik biçimde kullanılmıştır. ${ }^{41}$ Başka bir çalışmada, Pakistan'daki tuğla fabrikalarının çevre, ekonomi ve insan sağllğı üzerindeki etkilerinin incelenmesi maksadıyla DEMATEL, Bulanık TOPSIS yöntemiyle birlikte kullanılmıştır. ${ }^{42}$ Bir başka çalışmada, Malezya’daki sağlık turizmini etkileyen faktörler arasındaki ilişki ağının belirlenmesi ve bu faktörlerin göreceli önemlerinin tespit edilebilmesi için DEMATEL, Bulanık TOPSIS yöntemiyle bir arada kullanılırken; ${ }^{43}$

35 James J. H. Liou vd., "A Hybrid MCDM Model for Improving the Electronic Health Record to Better Serve Client Needs", Sustainability, 9/1819 (2017), s.1-13.

36 Sheng-Li Si vd., "Identifying Key Performance Indicators for Holistic Hospital Management with a Modified DEMATEL Approach”, Int. J. Environ. Res. Public Health, 14/934 (2017), s.1-17.

37 Miguel Angel Ortiz Barrios vd., "An Integrated Approach to Evaluate the Risk of Adverse Events in Hospital Sector", Management Decision, 56/10 (2018), s.2187-2224.

38 Feyyaz Cengiz Dikmen ve Yunus Taş, "Applying Dematel Approach to Determine Factors Affecting Hospital Service Quality in a University Hospital: A Case Study", Yönetim Bilimleri Dergisi/Journal of Administrative Sciences, 16/2 (2018), s.11-28.

39 Gökçe Candan, “İlaç Sektöründe Başarılı Tersine Lojistik Uygulamaları İçin Faktörlerin Değerlendirilmesi: Bulanık Mantık Temelli Yaklaşım”, İşletme Araştırmaları Dergisi, Journal of Business Research Turk, 10/3 (2018), s.592-605.

40 Youness Frichi, Fouad Jawab ve Said Boutahari, "The Mixed-Method 5W2D Approach for Health System Stakeholders Analysis in Quality of Care: An Application to the Moroccan Context", Int. J. Environ. Res. Public Health, 16/2899 (2019), s.1-25.

41 Akshay Hinduja ve Manju Pandey, "Assessment of Healthcare Waste Treatment Alternatives Using an Integrated Decision Support Framework”, International Journal of Computational Intelligence Systems, 12/1 (2019), s.318-333.

42 Muhammad Waseem Khan vd., "Impact of Brick Kilns Industry on Environment and Human Health in Pakistan", Science of the Total Environment, 678 (2019), s.383-389.

43 Mehrbakhsh Nilashi vd., "Factors Influencing Medical Tourism Adoption in Malaysia: A DEMATEL Fuzzy 
bir başka çalışmada, gelişmekte olan ekonomilerin (E7) evrensel sağlık kapsamlarını değerlendirmek maksadıyla Bulanık DEMATEL ve MOORA yöntemleri bir arada kullanılmıştır. $^{44}$

Gerçekleştirilen literatür araştırması, DEMATEL yönteminin sağlık sektörüne yönelik problemlerin çözümü amacıyla kullanıldığı çalışmaların sayıca çok sınırlı olduğunu göstermiştir. Türkiye'de DEMATEL yönteminin sağlıkla ilgili problemlerde kullanıldığı sadece iki çalışmaya rastlanmıştır. Söz konusu bu iki çalışmandan birinde DEMATEL yöntemi sağllk hizmetlerinin kalitesinin geliştirilmesi amacıyla; bir diğerinde ise, ilaç sektöründe tersine lojistik faaliyetlerinin değerlendirilmesi maksadıyla kullanılmıştır. Ayrıca, yapılan bu literatür araştırması DEMATEL yönteminin kaybedilen yaşam yılını etkileyen risk faktörleri arasındaki ilişkinin incelenmesi maksadıyla gerek ulusal gerek uluslararası ölçekte daha önce hiç kullanılmadığını göstermiştir. $\mathrm{Bu}$ açıdan, çalışmanın literatüre zenginlik katacağı, farklı yöntemlerin sağlık alanındaki sorunların analizi ve çözümü için kullanılabileceğine yönelik farkındalı̆̆ı arttıracağ 1 düşünülmektedir. Bunlara ek olarak, DEMATEL yöntemiyle araştırmaya konu olan risk faktörlerinin neden ve sonuç şeklinde gruplandırılması, sağlık politikalarını belirleyenlerin ve uygulayanların hangi risk faktörlerinin kaybedilen yaşam yılı üzerinde daha etkili olduklarını görmelerini sağlayarak insan ömrünü uzatmak maksadıyla hayata geçirilecek uygulamaların etkinliğini arttıracaktır. Esasen bu çalışmanın ortaya çıkmasının altında yatan temel neden de budur. Şöyle ki, kaybedilen yaşam yılını etkileyen risk faktörleri Sağlık Bakanlığı tarafından yayınlanan sağlık istatistikleri arasında yer alan temel istatistiklerden biridir. Mamafih, kaybedilen yaşam yılına etki eden risk faktörlerine yönelik yayınlanan istatistikler, söz konusu risk faktörleri arasında bir ilişki olup olmadığını anlamaya imkan vermemektedir. Sağlık programlarının televizyon, radyo, internet gibi mecralarda yayınlanmasının çok yaygınlaştığı ve popüler olduğu günümüz dünyasında; sadece, bu mecraları takip eden herhangi bir uzmanlığa sahip olmayan bireylerin dahi bahsedilen risk faktörleri arasında bir ilişki olabileceğine dair görüş bildirebilmeleri mümkündür. Elbette ki bu ifadeden sağllk gibi önemli bir konuda uzmanlığın gerekliliğin ve öneminin hafife alındığı asla ve kat’a anlaşılmamalıdır. Böyle bir ifade abesle iştigal etmekten öteye geçemeyeceği gibi kastedilmek isteneni de yansıtmaktan çok uzaktır. İfade edilmek istenen, teknolojinin gelişmesinin ve yaygınlaşmasının insanları sağlık konusunda bilinçlendirmesi ve sağlıkla ilgili konularda daha duyarlı hale getirmesidir. Bu çalışmama, zikredilen risk faktörleri arasındaki ilişkinin tıbbi ve deneysel araştırmalar dışındaki yöntemler kullanılarak da irdelenmesinin literatüre katkı yapacağı düşüncesinin bir tezahürü olarak ortaya çıkmıştır.

\section{Araştırma ve Araştırmanın Aşamaları}

Bu başlık altında, araştırmaya konu olan problemin tanımına, risk faktörlerinin nasıl seçildiğine, verilerin nereden ve hangi yolla toplandığına, kullanılan yönteme ilişkin detaylı açılamalara, analize ve analizle elde edilen bulgulara yer verilmiştir.

TOPSIS Approach", Computers and Industrial Engineering, 137/106005 (2019), s.1-13.

44 Xiaofeng Shi vd., "Hybrid Decision-Making Approach for the Service and Financial-Based Measurement of Universal Health Coverage for the E7 Economies”, Int. J. Environ. Res. Public Health, 16/3295 (2019), s.1-20. 


\section{Problemin Tanımı}

Farklı rahatsızlıklar ve yaralanmalar nedeniyle meydana gelen erken ölümler ile ölümle sonuçlanmayan fakat bireyin bedensel faaliyetlerinde ve sağlı̆̆ında bozulmalara neden olan hastalıkların neden olduğu hastalık yükünü; bir diğer ifadeyle, bireyin sağlıklı olarak geçireceği bir yılın kaybını ifade eden Engelliliğe Ayarlanmış Yaşam Yılları (DALY: Disability Adjusted Life Years) Ölçütü, Erken Ölümle Kaybedilen Yaşam Yılı (YLL) ve Engellilikle Geçirilen Yaşam Yılı (YLD) toplamını ifade etmektedir. ${ }^{45} \mathrm{Bu}$ çalışmada hastalık yükünün hesaplanmasında kullanılan DALY ölçütünün ${ }^{46}$; temel iki bileşeninden biri olan ve Sağlık Bakanlığı tarafından hazırlanan istatistiklerde de YLL ölçütü üzerinde belirleyici konumda yer aldığı ifade edilen başlica 19 risk faktörünün içsel ilişkilerinin tespit edilmesi, bu faktörlerden hangilerinin diğerleri üzerinde daha etkili olduğunun belirlenmesi ve söz konusu risk faktörlerinin hangilerinin daha fazla öneme sahip olduklarının belirlenebilmesi maksadıyla ağırlıklarının hesaplanması amaçlanmıştır. Bu yolla, kaybedilen yaşam yılı/ yılları üzerinde en etkili olan faktörlerin tespit edilerek, toplum sağlına ayrılan kamu kaynaklarının öncelikli olarak bu faktörlerin bertaraf edilmesine yönelik bir takım sağlık politikalarının geliştirilmesi ile ilgili fikir sunmak amaçlanmıştır.

\section{Kullanılan Veriler ve Verilerin Toplanması}

Bu araştırmada, T.C.Sağlık Bakanlığı tarafından yayınlanan 2017 Sağlık İstatistikleri Yıllığı’nda kaybedilen yaşam yılları üzerinde belirleyici konumda yer aldığı ifade edilen başlıca 19 risk faktörü dikkate alınmıştır. Bu faktörler, aile içi şiddet $\left(R_{1}\right)$; alkol kullanımı $\left(R_{2}\right)$; beslenmeyle ilgili riskler $\left(R_{3}\right)$; böbrek fonksiyon bozukluğu $\left(R_{4}\right)$; çevreyle ilgili diğer riskler $\left(R_{5}\right)$; çocuk ve annede malnütrisyon $\left(R_{6}\right)$; çocuklukta kötü muameleye maruz kalma $\left(R_{7}\right)$; çocuklukta kötü muameleye maruz kalma $\left(R_{8}\right)$; güvenli olmayan su, sanitasyon ve el yıkama $\left(R_{9}\right)$; hava kirliliği $\left(R_{10}\right)$; korunmasız cinsel ilişki $\left(R_{11}\right)$; madde kullanımı $\left(R_{12}\right)$; mesleki riskler $\left(R_{13}\right)$; tütün kullanımı (aktif ve pasif) $\left(R_{14}\right)$; yetersiz fiziksel aktivite $\left(R_{15}\right)$; yüksek açlik kan şekeri $\left(R_{16}\right)$; yüksek LDL kolesterol $\left(R_{17}\right)$; yüksek sistolik kan basıncı $\left(R_{18}\right)$ ve yüksek beden kitle indeksi $\left(R_{19}\right)$ şeklinde sıralanmaktadır. Araştırmada kullanılan bu 19 risk faktörü arasındaki neden sonuç ilişkisinin açığa çıkarılabilmesi için kullanılan DEMATEL yöntemi gereği uzman görüşlerine ihtiyaç duyulmuştur.

Bu bağlamda Ondokuz Mayıs Üniversitesi Tıp Fakültesi Halk Sağlığı Ana Bilim Dalı’ndan araştırma için gerekli destek ve izin talep edilmiş, gelen olumlu yanıt üzerine Halk Sağlı̆̆ı Ana Bilim Dalı'nda görev yapmakta olan öğretim elemanlarına DEMATEL uzman görüş formları elden teslim edilmiştir. Uzmanların kişisel görüşlerini yansıtan 18 form geri dönmüştür. Belirlenen risk faktörleri arasındaki neden sonuç ilişkisinin ortaya çıkarılması için söz konusu formlarda yer alan birincil veriler dikkate alınmıştır.

45 Deniz Tugay Arslan ve İsmail Ağırbaş, “Sağlık Çıktılarının Ölçülmesi: QALY ve DALY”, Sağlıkta Performans ve Kalite Dergisi, 13 (2017), s.111.

46 T.C. Sağlık Bakanlığı Temel Sağlık Hizmetleri Genel Müdürlüğü, Ulusal Ruh, s.5. 


\section{DEMATEL Yöntemi}

Bu çalışmada kaybedilen yaşam yıllarını etkileyen 19 risk faktörü arasındaki içsel ilişkilerin belirlenmesi, hangi faktörlerin etkileyen hangilerinin etkilenen olduklarının tespit edilmesi ve son olarak faktör ağırlıklarının hesaplanabilmesi için uzman görüşüne dayalı çok kriterli karar verme yöntemlerinden biri olan DEMATEL yöntemi kullanılmıştır. Yöntem, İsviçre’nin Cenevre şehrinde bulunan Battelle Memorial Enstitüsü’nde 1972-1976 yılları arasında birbirleriyle ilişkili, karmaşık problem yapılarını araştırmak ve çözüme kavuşturmak maksadıyla geliştirilmiştir. ${ }^{47} \mathrm{Bu}$ tür problem yapılarında aralarında karşılıklı ilişkilerin var olduğu, nihai sonucu etkileyebilme özelliğine sahip pek çok ana ve alt kriter; bu kriterleri dikkate alarak değerlendirilmesi gereken çok sayıda alternatif veya karar noktası mevcuttur. Kriterlerden hiçbiri tek başına nihai sonuca ulaşma; bir başka ifadeyle alternatifler arasından en iyisinin seçilmesi noktasında kafi gelmemektedir. Dolayısıyla, ele alınan problemin sağlıklı bir şekilde çözüme kavuşturulması için tüm değerlendirme kriterlerinin aynı anda dikkate alınması gerekmektedir. Aralarında ilişki bulunan kriterlerden oluşan ÇKKV problemlerinin doğrusal çözümü hatalı sonuçlara neden olabilir. Bununla birlikte, tamamen birbirleriyle ilişkili bir sistemde de herhangi bir kritere yapılacak müdahale diğer kriterleri etkileyeceğinden ve söz konusu kriterlerin önceliklerinin belirlenmesi oldukça zor bir iştir. DEMATEL yöntemi, bu tür kompleks problemlerde grafik teorisi kavramlarını kullanarak karar vericiler için problemi görselleştirmekte ve problemin daha iyi anlaşılmasına yardımcı olmaktadır. ${ }^{48}$ DEMATEL ile kriterler arasındaki dahili ilişkileri ortaya koyan bir ilişki haritası oluşturulabileceği gibi; aynı zamanda yöntem, nedensellik diyagramları vasıtasıyla alt sistemlerin nedensellik ilişkilerinin görselleştirilebilmesine imkan tanımaktadır. ${ }^{49}$ Yöntem, aralarında dahili ilişkiler bulunan çeşitli faktörler üzerine inşa edilmiş bir sistemde faktörler arasında bir doğrudan ilişki matrisi oluşturur. Bu yolla yöntem, faktörlerin birbirlerini etkileme ve birbirlerinden etkilenme derecelerini hesaplamaya; ${ }^{50}$ sistemi oluşturan faktörleri neden ve sonuç grupları şeklinde sınıflandırmaya ve sistemdeki başlıca faktörleri belirlemeye, ${ }^{51}$ aynı zamanda, faktörleri ağırlıklandırmaya da imkan vermektedir. ${ }^{52}$ $\mathrm{Bu}$ açıdan DEMATEL, bir problemin bileşenleri arasındaki neden ve sonuç ilişkilerini hesaplamak için matematiksel teorilerle ilişkili ve matrisleri kullanan analitik bir yöntem olarak kabul edilmektedir. ${ }^{53}$ Yöntem, gerçek hayatta karşılaşılan problemler için oldukça uygun olduğundan çok çeşitli karar verme probleminde yaygın bir kullanıma sahiptir. ${ }^{54}$ Bununla birlikte DEMATEL, insan faktörünün neden olduğu

47 Dong-Shang, Shu-Ming ve Yi-Chun, "Applying DEMATEL", s.1249.

48 Akshay Hinduja ve Manju Pandey, "Assessment of Healthcare" s.320.

49 Gülçin Büyüközkan ve Sezin Güleryüz, "An Integrated DEMATEL-ANP Approach for Renewable Energy Resources Selection in Turkey", International Journal of Production Economics, 182 (2016), s.437.

50 Xiujuan Chen vd., "Influential Impacts of Combined Government Policies for Safe Disposal of Dead Pigs on

Farmer Behavior", Environmental Science and Pollution Research, 24 (2017), s.4000.

51 Youness, Fouad ve Said, “The Mixed-Method 5W2D”, s.7.

52 Xiaofeng vd., "Hybrid Decision-Making", s.5.

53 Anil Kumar vd., "Investigating the Role of Social Media in Polio Prevention in India: A Delphi-DEMATEL

Approach”, Kybernetes, 47/5 (2018), s.1058.

$54 \mathrm{Hu}-\mathrm{Chen} \mathrm{Liu} \mathrm{vd.,} \mathrm{"Evaluating} \mathrm{Health-Care",} \mathrm{s.933.}$ 
öznelliği ve veri setindeki belirsizliği ortadan kaldırmada yetersiz kaldığ $1,{ }^{55}$ gerekçesiyle eleştirilebilmektedir. Yöntemin temel aşamaları aşağıda aşama aşama gösterilmiştir: ${ }^{56}$

1.Aşama: Eşitlik (1)'de $S$ ile temsil edilen doğrudan ilişsi matrisinin tesis edilmesi. $S$ matrisinin oluşturulabilmesi için uzmanların bireysel değerlendirmelerinin alınması gerekmektedir. Bu bağlamda, araştırmada Tablo 1'de gösterilen sözel ifadeler ve bu ifadelere karşılık gelen sayısal değerler kullanılmıştır.

Tablo 1: Uzmanların Bireysel Değerlendirmeleri için Kullandıkları Ölçek

\begin{tabular}{cc}
\hline Sözel İfadeler & Sözel İfadelere Karşılık Gelen Sayısal Değerler \\
\hline Çok yüksek etkili & 3 \\
Yüksek etkili & 2 \\
Etkili & 1 \\
Etkisiz & 0 \\
\hline
\end{tabular}

(Aktaş vd, 2015, 225)

Bu araştırmada $i$ ve $j$ YLL'yi etkileyen risk faktörlerini ifade etmekte olup; $i=1,2, \ldots$, $t v e j=1,2, \ldots, t$ 'dir. $S$ doğrudan ilişki matrisindeki $s_{i j} i$ inci risk faktörünün $j$ inci risk faktörü üzerindeki etkisinin değerini göstermektedir.

$$
S=\left[\begin{array}{ccc}
S_{11} & \cdots & s_{1 j} \\
\vdots & \ddots & \vdots \\
S_{i 1} & \cdots & s_{i j}
\end{array}\right], i, j=1,2, \ldots, t
$$

2.Aşama: Doğrudan ilişki matrisinin tesis edilmesini takiben, Eşitlik (2) ile gösterilen formül kullanılarak normalize edilmiş değerlerin hesaplanması ve Eşitlik (3)'de $\tilde{S}$ ile temsil edilen normalize edilmiş doğrudan ilişki matrisinin ihdas edilmesi gerekmektedir.

$$
\begin{aligned}
& x=\max \left[\max _{j}\left(\sum_{i=1}^{t} S_{i j}\right), \max _{i}\left(\sum_{j=1}^{t} S_{i j}\right)\right] \\
& \tilde{S}=x^{-1} \otimes S
\end{aligned}
$$

3.Aşama: Eşitlik (4) vasıtasıyla; Eşitlik (5)'de ile gösterilen toplam ilişki matrisinin tesis edilmesi. Eşitlik (5)'de yer alan “ $y_{i j}$ ”, $i$ 'inci risk faktörünün $j$ 'inci risk faktörüyle

55 Glory George-Ufot, Ying Ou, Ifeyinwa Juliet Orji, “Sustainable Lifestyle Factors Influencing Industries' Electric Consumption Patterns Using Fuzzy Logic and DEMATEL: The Nigerian Perspective", Journal of Cleaner Production, 162 (2017), s.627.

56 Anil Kumar vd., "Investigating the Role" ss.1058-1059; Wen-Hsien Tsai ve Wen-Chin Chou, "Selecting Management Systems for Sustainable Development in SMEs: A Novel Hybrid Model Based on DEMATEL, ANP, and ZOGP", Expert Systems with Applications, 36 (2009), s.1454. 
arasındaki toplam ilişki derecesini ifade etmektedir.

$$
\begin{aligned}
Y & =\tilde{S}(I-\tilde{S})^{-1} \\
Y & =\left[\begin{array}{ccc}
y_{11} & \cdots & y_{1 j} \\
\vdots & \ddots & \vdots \\
y_{i 1} & \cdots & y_{i j}
\end{array}\right], i, j=1,2, \ldots, t
\end{aligned}
$$

4.Aşama: $i$ 'inci risk faktörünün diğer risk faktörlerine doğrudan veya dolaylı etkileri toplamını ifade eden $K_{i}$ matrisinin oluşturulması için Eşitlik (6)'daki; $i$ 'inci risk faktörünün diğer risk faktörlerinden etkilenme derecesini gösteren $N_{i}$ matrisinin tesis edilmesi için Eşitlik (7)'deki formül kullanılır. olmak üzere:

$$
\begin{aligned}
& K_{i}=\left[\sum_{j=1}^{t} y_{i j}\right]_{t x 1} \\
& N_{i}=\left[\sum_{i=1}^{t} y_{i j}\right]_{1 x t}
\end{aligned}
$$

Şayet; $K_{i}-N_{i}>0$ ise, $i$ 'inci risk faktörü diğer risk faktörleri üzerinde etkili olan bir faktördür. Fakat aksine; $K_{i}-N_{i}<0$ ise, $i$ inci risk faktörü diğer risk faktörlerinden etkilenen bir faktördür.

5.Aşama: Etkileyen ve etkilenen risk faktörlerinin belirlenmesinden sonra, uzman görüşü ya da toplam ilişki matrisinde yer alan değerlerin ortalamaları alınmak suretiyle belirlenir. Belirlenen eşik değeri dikkate alınarak risk faktörleri arasındaki içsel ilişkileri gösteren ilişki diyagramı çizilir.

6.Aşama: Risk faktörlerinin öneme derecelerinin belirlenebilmesi için ağırlıklarının hesaplanması. Eşitlik (8)'de $v_{i}$ ile temsil edilen $i$ 'inci risk faktörü ağırlığının hesaplanabilmesi için Eşitlik (9)'daki formülden faydalanılır. $i=1,2, \ldots, t v e j=1,2, \ldots, t$ olmak üzere:

$$
\begin{aligned}
& p_{i}=\frac{z_{i}}{\sum_{i=1}^{t} z_{i}} \\
& z_{i}=\sqrt{\left(\left(K_{i}+N_{i}\right)^{2}+\left(K_{i}-N_{i}\right)^{2}\right)}
\end{aligned}
$$

\section{Analiz}

Çalışmanın bu kısmında araştırmaya konu olan ve YLL ölçütü üzerinde etkili olan 19 risk faktörü arasındaki içsel ilişkilerin açığa çıkarılması için DEMATEL yöntemi kullanılarak gerçekleştirilen analize yer verilmiştir. Söz konusu 19 risk faktörü Tablo 2'de gösterilmiştir. 
Risk faktörlerinin belirlenmesinden sonra, araştırmaya katkı vermeyi kabul eden uzman hekimlere DEMATEL formları gönderilmiş ve bu formlarda yer alan risk faktörlerini Tablo 1'de gösterilen değerlendirme ölçeğini kullanarak doldurmaları istenmiştir. Bu yolla elde edilen 18 adet DEMATEL uzman görüşü formunda yer alan değerlerin aritmetik ortalaması alınarak Eşitlik (1)'deki doğrudan ilişki matrisi oluşturulmuş ve Tablo 3'de gösterilmiştir. Bu aşamayı takiben, Eşitlik (2) ile gösterilen formül kullanılarak normalize edilmiş değerler hesaplanmış ve Eşitlik (3)'de ile gösterilen normalize edilmiş doğrudan ilişki matrisi ihdas edilmiştir. Söz konusu matris Tablo 4'de gösterilmiştir. Bir sonraki aşamada, Eşitlik (5)'de ile gösterilen toplam ilişki matrisi oluş̧urulmuş ve Tablo 5'de gösterilmiştir. Eşik değerinin hesaplanması için toplam ilişki matrisinde yer alan değerlerin ortalaması alınmıştır. Risk faktörleri arasındaki içsel ilişkileri gösterirken; bir diğer ifadeyle, ilişki diyagramı çizilirken 0,005061' lik eşik değerini aşan ilişkiler dikkate alınmıştır. Bu ilişkileri gösteren ilişki diyagramı Şekil l'de gösterilmiştir. Eşitlik (6) ve Eşitlik (7)'de yer alan formüller kullanılarak hangi risk faktörlerinin etkileyen hangilerinin etkilenen oldukları belirlenmiş ve Tablo 6'da gösterilmiştir. Etkileyen ve etkilenen risk faktörlerinin belirlenmesi ve ilişki diyagramının çizilmesinden sonra Eşitlik (8) vasıtasıyla 19 risk faktörünün her birinin ağırlıkları hesaplanmıştır. Her bir risk faktörünün ağırlığı, önem derecesine göre, Tablo 7'de gösterilmiştir. DEMATEL yöntemi gereği analiz kapsamında oluşturulan matrislerin oldukça fazla yer kaplaması nedeniyle, söz konusu matrisler ve ilişki diyagramı yukarıda ifade edilen sırayı takip edecek şekilde aşağıda ardı ardına gösterilmiştir. 
Tablo 2: YLL Üzerinde Etkili Olan Başlica 19 Risk Faktörü

\begin{tabular}{|c|c|c|c|c|c|c|c|c|c|c|c|c|c|c|c|c|c|c|}
\hline 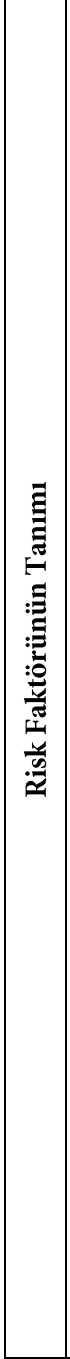 & 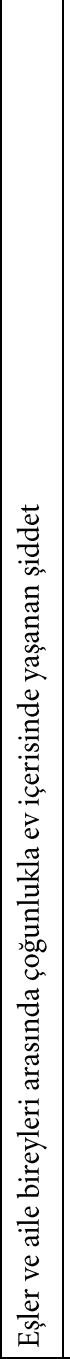 & 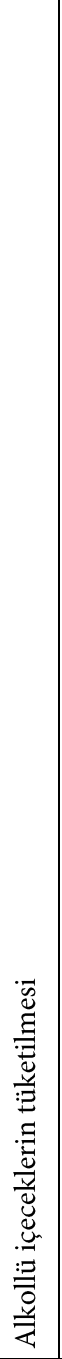 & 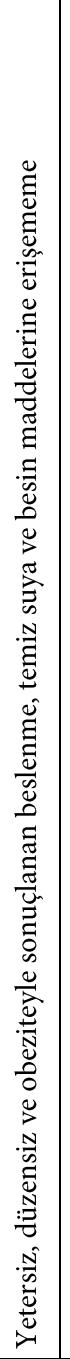 & 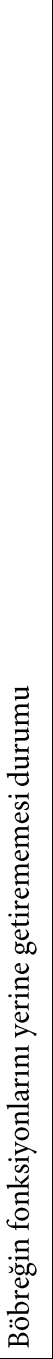 & 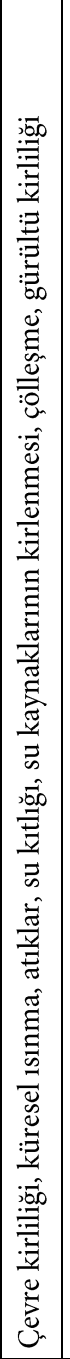 & 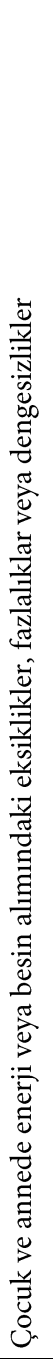 & 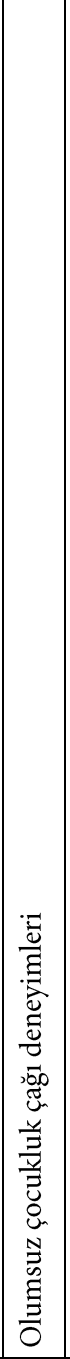 & 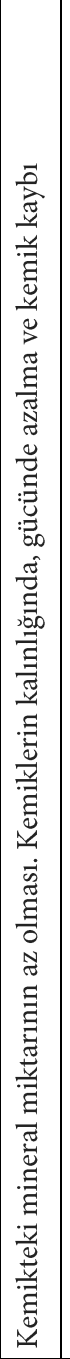 & 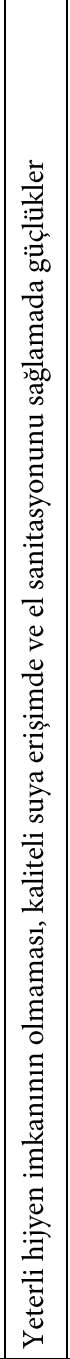 & 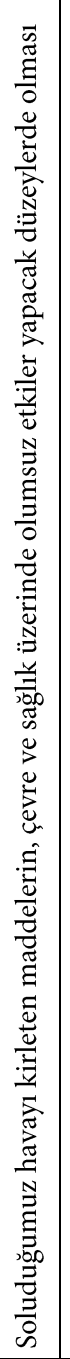 & 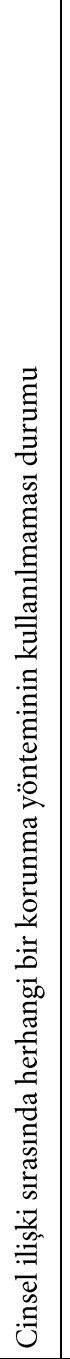 & 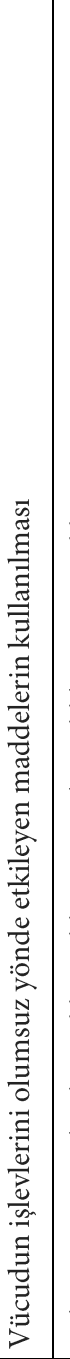 & 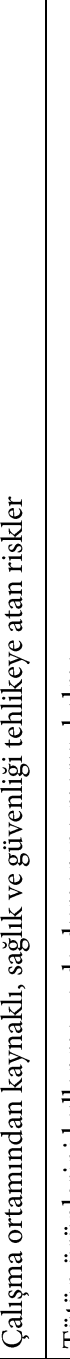 & 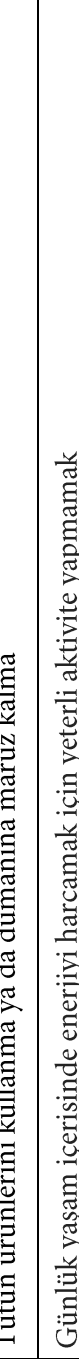 & | & 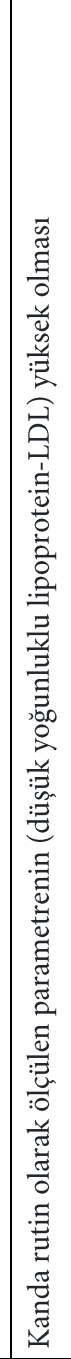 & 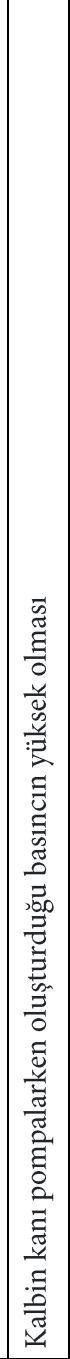 & 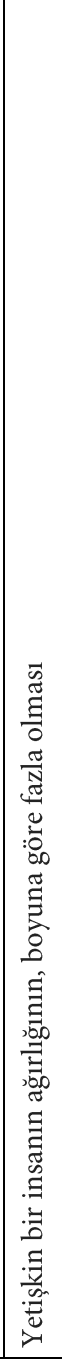 \\
\hline 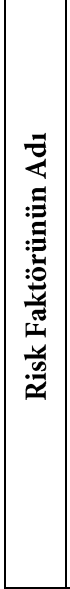 & 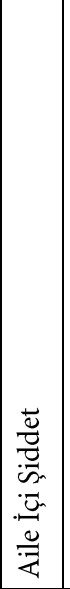 & 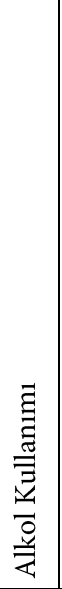 & 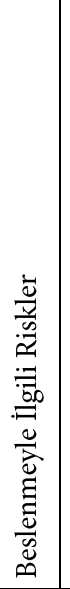 & 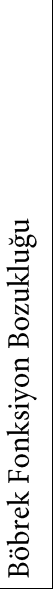 & 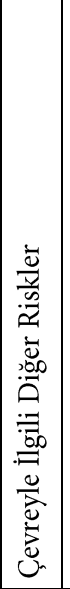 & 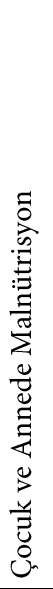 & 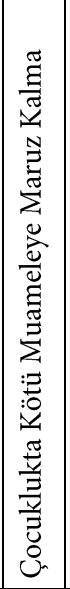 & 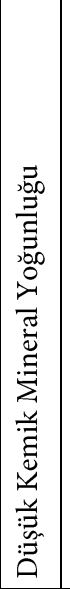 & 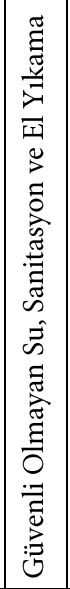 & 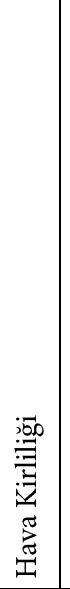 & 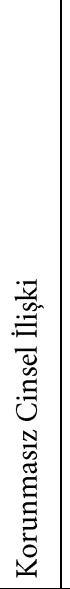 & 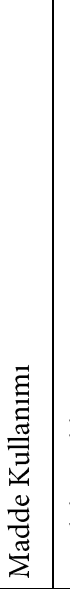 & $=$ & 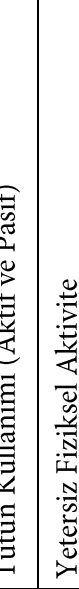 & 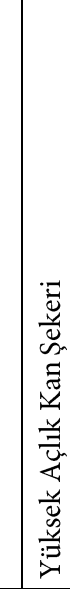 & 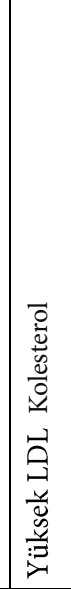 & 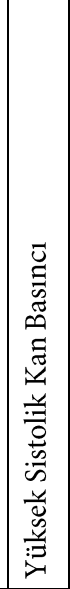 & 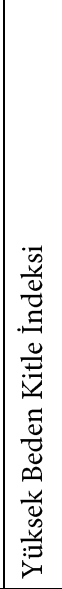 \\
\hline$\vec{a}$ & $\approx$ & $\approx$ & $\approx$ & $\approx$ & $\approx$ & $\approx$ & $\approx$ & $\approx$ & $\approx$ & $\approx$ & $\approx$ & $\approx$ & $\approx$ & $\approx$ & $\approx$ & $\approx$ & $\approx$ & $\approx$ \\
\hline
\end{tabular}


Tablo 3: Doğrudan İlişki Matrisi (S)

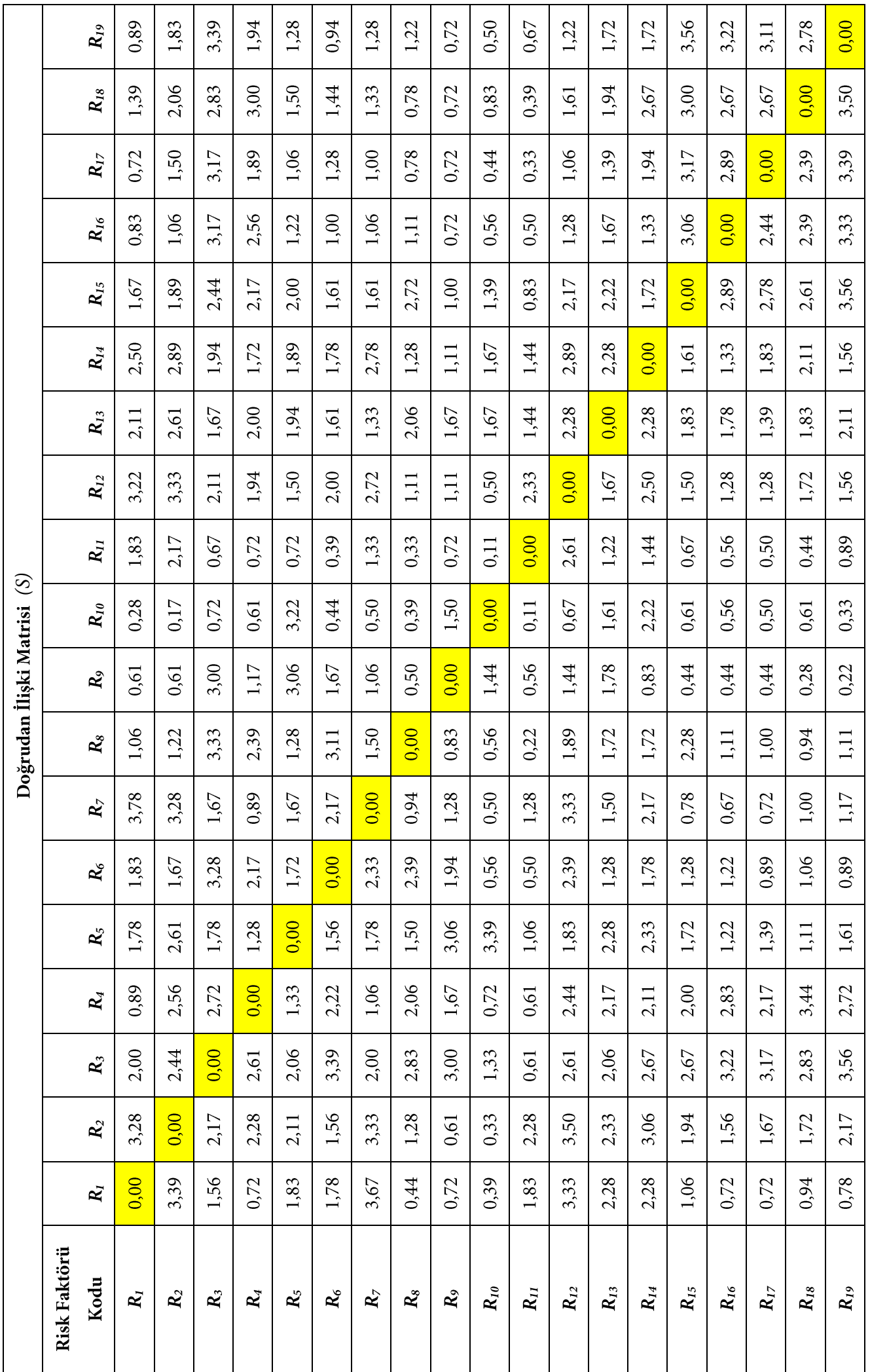




\section{Tablo 4: Normalize Edilmiş Doğrudan İlişki Matrisi $(\widetilde{S})$}

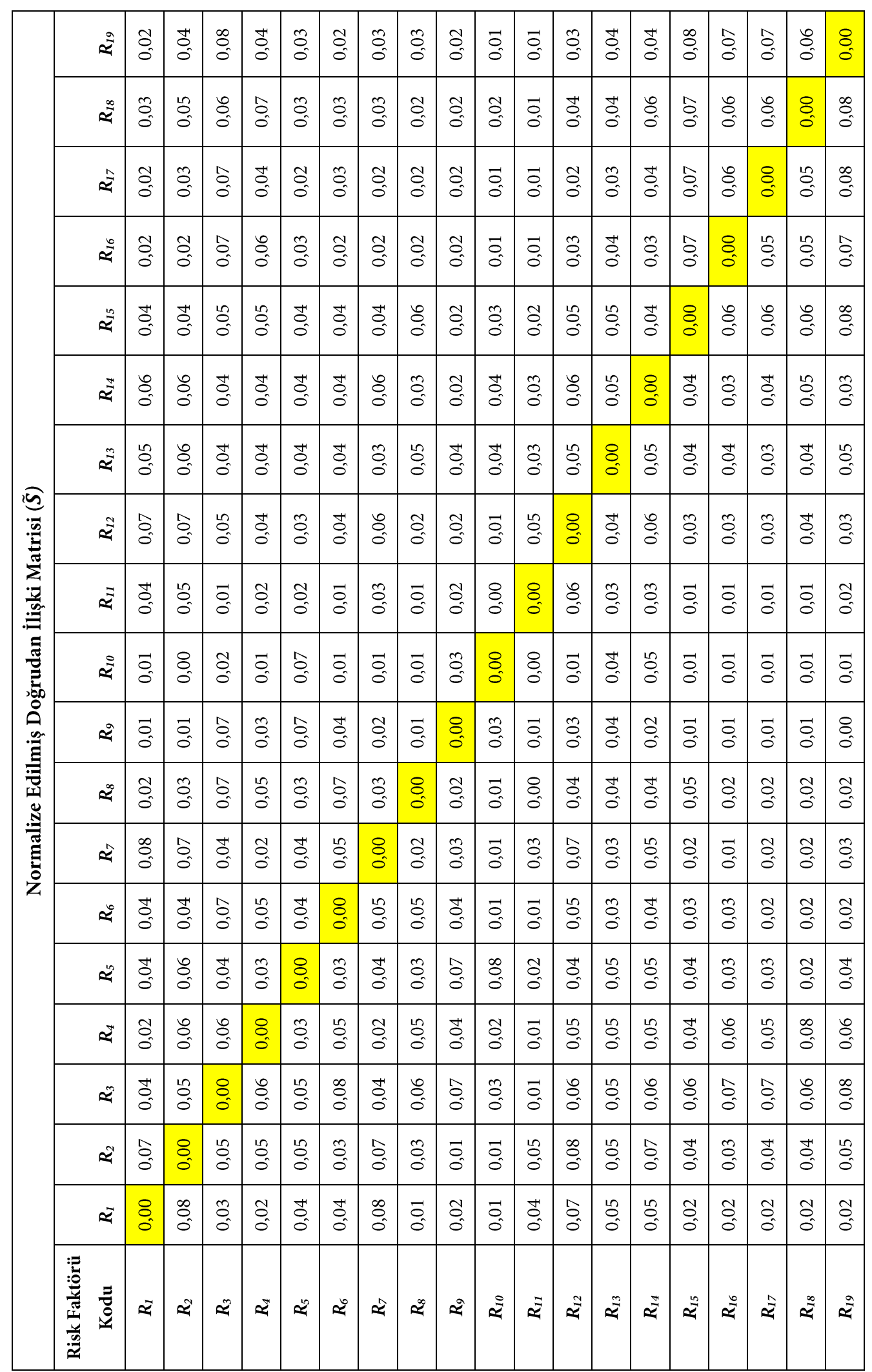


Tablo 5: Toplam İlişki Matrisi (Y) ve Eşik Değeri

\begin{tabular}{|c|c|c|c|c|c|c|c|c|c|c|c|c|c|c|c|c|c|c|c|c|}
\hline & $\approx$ & $\begin{array}{c}\text { त̂: } \\
\vdots \\
\vdots \\
\vdots\end{array}$ & 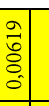 & | & & 资 & 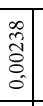 & 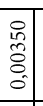 & $\begin{array}{l}\text { D. } \\
0 \\
0 \\
0 \\
\end{array}$ & $\begin{array}{l}0 \\
0 \\
0 \\
0 \\
0\end{array}$ & 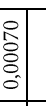 & & 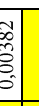 & & & & & & & \\
\hline & $\approx$ & 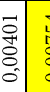 & $\begin{array}{l}\text { r. } \\
0 \\
0 \\
0 \\
0\end{array}$ & $\begin{array}{c}\text { ב⿱ } \\
\vdots \\
\vdots\end{array}$ & 党: & 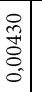 & 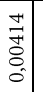 & 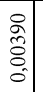 & $\begin{array}{l}\vec{z} \\
\vec{a} \\
\vdots \\
0\end{array}$ & 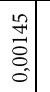 & 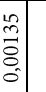 & & & & & & & & & \\
\hline & $\stackrel{A}{\approx}$ & & 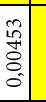 & 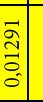 & : & 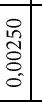 & 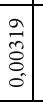 & $\begin{array}{l} \\
\text { J } \\
\text { o. } \\
0 \\
0\end{array}$ & 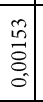 & 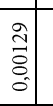 & | & | & | & 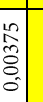 & & & & & & \\
\hline & $\stackrel{0}{\approx}$ & & 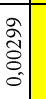 & 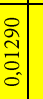 & $\begin{array}{l}0 \\
0 \\
0 \\
0 \\
0\end{array}$ & $\begin{array}{ll} \\
\vdots \\
\vdots \\
\vdots \\
0 \\
0\end{array}$ & 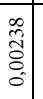 & 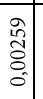 & 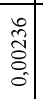 & $\begin{array}{l}\text { ज्ञ } \\
\vdots \\
\vdots \\
0\end{array}$ & 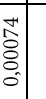 & 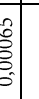 & : & 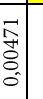 & 赵 & 0 & & & & \\
\hline & $\frac{a}{2}$ & & 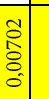 & 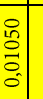 & 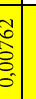 & 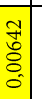 & 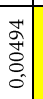 & 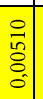 & $\begin{array}{c}0 \\
0 \\
0 \\
0 \\
0 \\
0\end{array}$ & 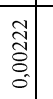 & 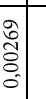 & $\frac{6}{8}$ & |ct & 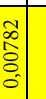 & 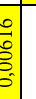 & & & & & \\
\hline & $\bar{z}$ & & 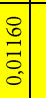 & : & $\begin{array}{c}0 \\
0 \\
0 \\
0\end{array}$ & 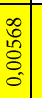 & 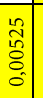 & \begin{tabular}{c|c|} 
& \\
0 \\
$\vdots$ \\
$\vdots$ \\
0
\end{tabular} & 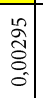 & $\begin{array}{l}\hat{a} \\
\vdots \\
0 \\
0\end{array}$ & | & 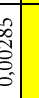 & 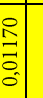 & | & 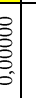 & 0 & 0 & 0 & & \\
\hline & $\stackrel{M}{\approx}$ & & \begin{tabular}{l|l}
$\overrightarrow{\vec{c}}$ \\
$\stackrel{0}{0}$ \\
0 \\
0
\end{tabular} & & 范 & 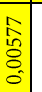 & 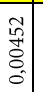 & 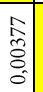 & \begin{tabular}{l|l} 
& \\
0 \\
0 \\
0 \\
0 \\
0
\end{tabular} & & 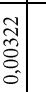 & है. & 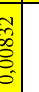 & 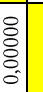 & 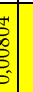 & 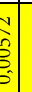 & : & 0 & & \\
\hline & $\approx$ & & \begin{tabular}{l|l} 
& \multicolumn{2}{c}{} \\
$\vdots$ \\
$\vdots$ \\
0
\end{tabular} & 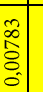 & 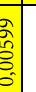 & 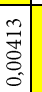 & 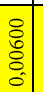 & 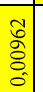 & 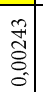 & $\begin{array}{c}\overrightarrow{\hat{\pi}} \\
\bar{\delta} \\
0 \\
0\end{array}$ & 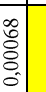 & 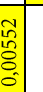 & 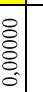 & $\mid$ & & : & : & $\begin{array}{l}8 \\
0 \\
0\end{array}$ & E. & \\
\hline & $\bar{\approx}$ & & $\begin{array}{l}0 \\
0 \\
\vdots \\
\vdots \\
0 \\
0\end{array}$ & 范 & - & 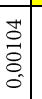 & 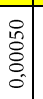 & $\begin{array}{ll} & \\
\vdots \\
\vdots \\
0 \\
0 \\
0\end{array}$ & 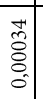 & $\begin{array}{c}\text { rat } \\
0 \\
0 \\
0 \\
0\end{array}$ & $\begin{array}{l}1 \\
\\
0 \\
0 \\
0\end{array}$ & : & $\mid$ & 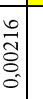 & 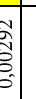 & 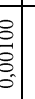 & 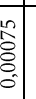 & 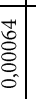 & & \\
\hline & $\approx$ & & $\begin{array}{c}\vec{a} \\
\bar{\Xi} \\
0 \\
0\end{array}$ & ت্: & 点 & 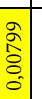 & $\begin{array}{ll} & \overrightarrow{1} \\
\vdots \\
0 \\
0\end{array}$ & $\mid$\begin{tabular}{l|}
$\overrightarrow{0}$ \\
$\vdots$ \\
0 \\
0
\end{tabular} & $\begin{array}{c}1 \\
0 \\
\vdots \\
0 \\
0 \\
0\end{array}$ & 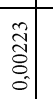 & $\begin{array}{l} \\
\vdots \\
\vdots \\
0\end{array}$ & 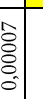 & 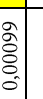 & 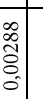 & $\infty$ & 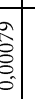 & 8 & N & 8 & \\
\hline & $\approx$ & \begin{tabular}{l|l}
0 \\
0 \\
0 \\
0
\end{tabular} & : & 范 & 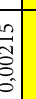 & 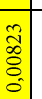 & 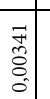 & $\begin{array}{l}\overrightarrow{\vec{a}} \\
\overline{0} \\
0\end{array}$ & 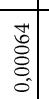 & $\begin{array}{l} \\
\\
0 \\
0\end{array}$ & 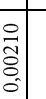 & $\mid$ & 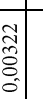 & 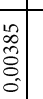 & : & 8 & 8 & N & 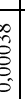 & \\
\hline & $\approx$ & 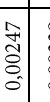 & $\begin{array}{l}0 \\
\hat{心} \\
0 \\
0 \\
0\end{array}$ & $\begin{array}{l}\overline{0} \\
\overrightarrow{0} \\
0 \\
0\end{array}$ & 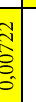 & 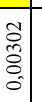 & 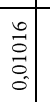 & \begin{tabular}{l|} 
\\
$\infty$ \\
0 \\
0 \\
0 \\
0
\end{tabular} & $\begin{array}{l}0 \\
\vdots \\
\vdots \\
0\end{array}$ & \begin{tabular}{l|} 
\\
$g$ \\
0 \\
0 \\
0
\end{tabular} & $\begin{array}{ll} & \\
0 \\
0 \\
\vdots \\
0 \\
0\end{array}$ & 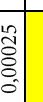 & 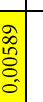 & | & 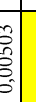 & 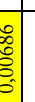 & 8 & 8 & 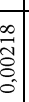 & \\
\hline & $\approx$ & & 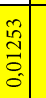 & | & : & 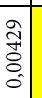 & $\begin{array}{l}0 \\
\vdots \\
0 \\
0 \\
0\end{array}$ & $\begin{array}{l}0 \\
0 \\
0 \\
0 \\
0\end{array}$ & $\begin{array}{l}\hat{A} \\
\stackrel{0}{0} \\
0\end{array}$ & $\begin{array}{l}0 \\
0 \\
0 \\
0 \\
0 \\
0\end{array}$ & 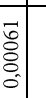 & : & 帘 & 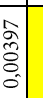 & & & ? & 8 & & \\
\hline & $\approx$ & & 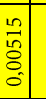 & | & 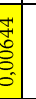 & \begin{tabular}{c|c|}
0 \\
$\vdots$ \\
$\vdots$ \\
0 \\
0 \\
0
\end{tabular} & $\begin{array}{l}\text { ô } \\
\vdots \\
0 \\
0\end{array}$ & $\begin{array}{l}0 \\
0 \\
0 \\
0 \\
0\end{array}$ & $\begin{array}{l}\text { के } \\
\text { ठे } \\
0\end{array}$ & $\begin{array}{l}0 \\
0 \\
0 \\
0 \\
0 \\
0\end{array}$ & 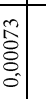 & |م: & 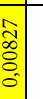 & 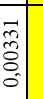 & & & 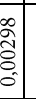 & 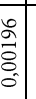 & & \\
\hline & $\approx$ & & 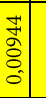 & 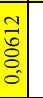 & 曾 & $\begin{array}{l} \\
\vdots \\
\vdots \\
0\end{array}$ & $\begin{array}{l}0 \\
0 \\
\mathbb{1} \\
0 \\
0\end{array}$ & 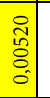 & $\begin{array}{l}\text { f^| } \\
0 \\
0 \\
0\end{array}$ & $\begin{array}{l}\text { col } \\
0 \\
0 \\
0 \\
0\end{array}$ & 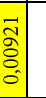 & |. & 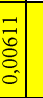 & | & & 8 & 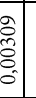 & 8 & & \\
\hline & $\approx$ & : & \begin{tabular}{ll|l} 
\\
$\vdots$ \\
$\vdots$ \\
$\vdots$ \\
$\vdots$
\end{tabular} & $\begin{array}{l}\infty \\
: \\
:\end{array}$ & 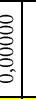 & 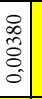 & $\begin{array}{l}\tilde{\tilde{U}} \\
0 \\
0 \\
0\end{array}$ & 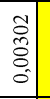 & $\begin{array}{l}1 \\
0 \\
0 \\
0 \\
0 \\
0\end{array}$ & \begin{tabular}{l}
0 \\
\multirow{z}{*}{} \\
0 \\
0 \\
0
\end{tabular} & 莗 & 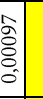 & 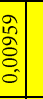 & | & & & 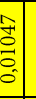 & 8 & 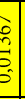 & \\
\hline & $\approx$ & : & 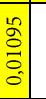 & 0 & 8 & 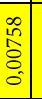 & \begin{tabular}{l|l} 
\\
0 \\
0 \\
0 \\
0 \\
0
\end{tabular} & \begin{tabular}{l|l} 
\\
0 \\
0 \\
0 \\
0
\end{tabular} & $\begin{array}{l}1 \\
0 \\
0 \\
0 \\
0\end{array}$ & : & 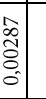 & : & | & 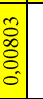 & & & ? & 0 & & \\
\hline & $\approx$ & & : & $\begin{array}{l}1 \\
\text { of } \\
\text { ò } \\
\text { d. }\end{array}$ & : & 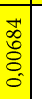 & \begin{tabular}{l} 
fo \\
\multirow{0}{0}{} \\
0 \\
0
\end{tabular} & \begin{tabular}{l|l} 
& \\
0 \\
0 \\
0 \\
0
\end{tabular} & $\begin{array}{l}\overrightarrow{4} \\
0 \\
0 \\
0 \\
0\end{array}$ & $\begin{array}{l}\vec{Z} \\
\vdots \\
0 \\
0\end{array}$ & 童 & 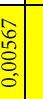 & |t: & 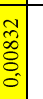 & 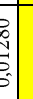 & & 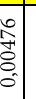 & 8 & & \\
\hline & $\approx$ & : & 苛: & 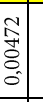 & 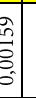 & 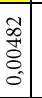 & 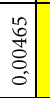 & $\overline{0}$ & $\begin{array}{l}8 \\
0 \\
0\end{array}$ & 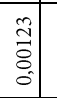 & : & | & 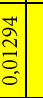 & 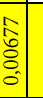 & & & & & & \\
\hline & 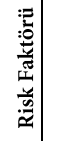 & & & $\approx$ & & $\approx$ & $\approx$ & $\approx$ & $\approx$ & $\approx$ & $\approx$ & $\approx$ & $\approx$ & $\approx$ & & & & & & \\
\hline
\end{tabular}

Not: Renklendirilen hücreler, risk faktörleri arasındaki ilişkinin eşik değerini aşıı̆̆ını göstermektedir. Eşik Değeri: 0,005061 
Tablo 6: Etkileyen ve Etkilenen Risk Faktörleri

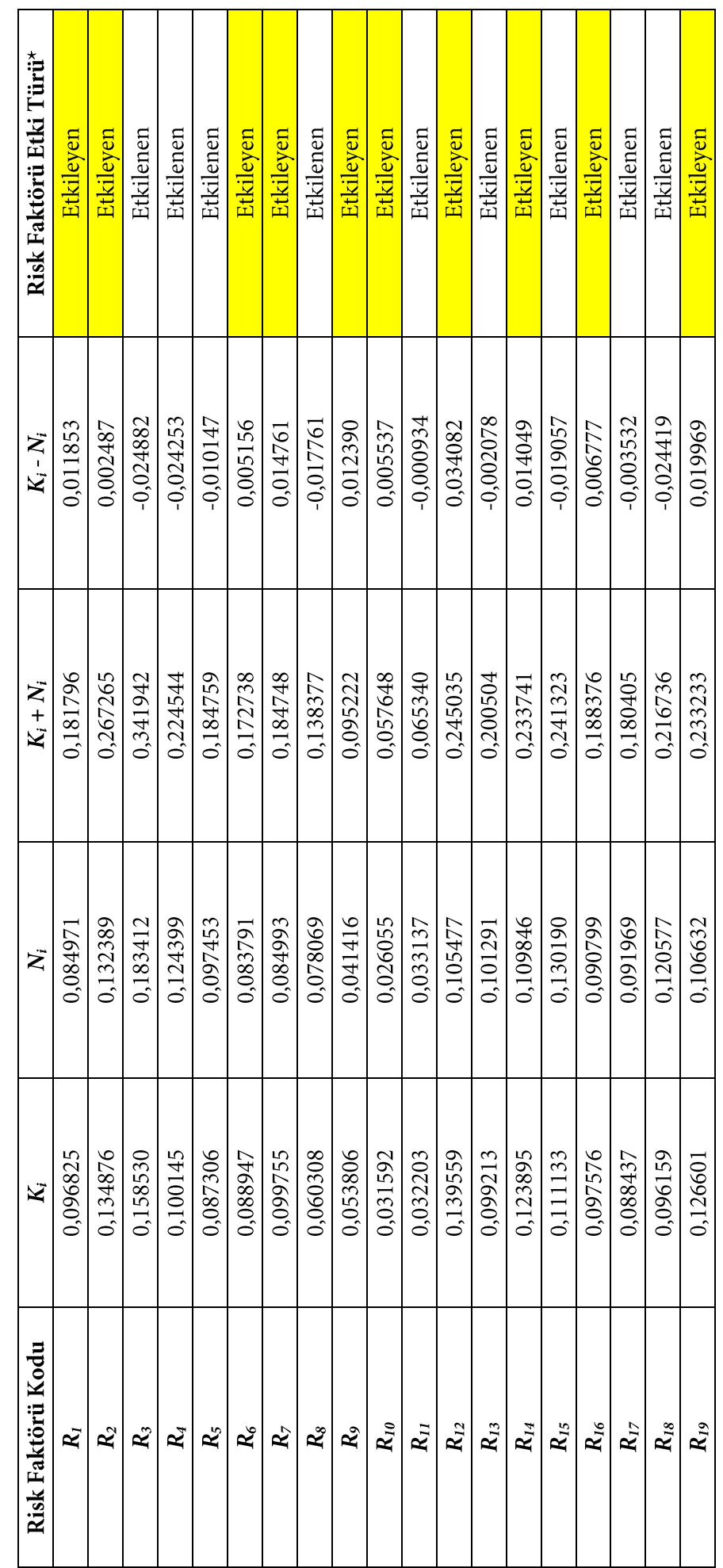

^Risk Faktörünün Etki Türü: Risk faktörünün diğer risk faktörleri üzerindeki etkisini ifade etmektedir. Risk faktörü etki türü "etkileyen” ise diğer faktörleri etkilediğini; aksi takdirde diğer faktörlerden etkilendiğini göstermektedir. 


\section{Şekil 1: İlişki Diyagramı}

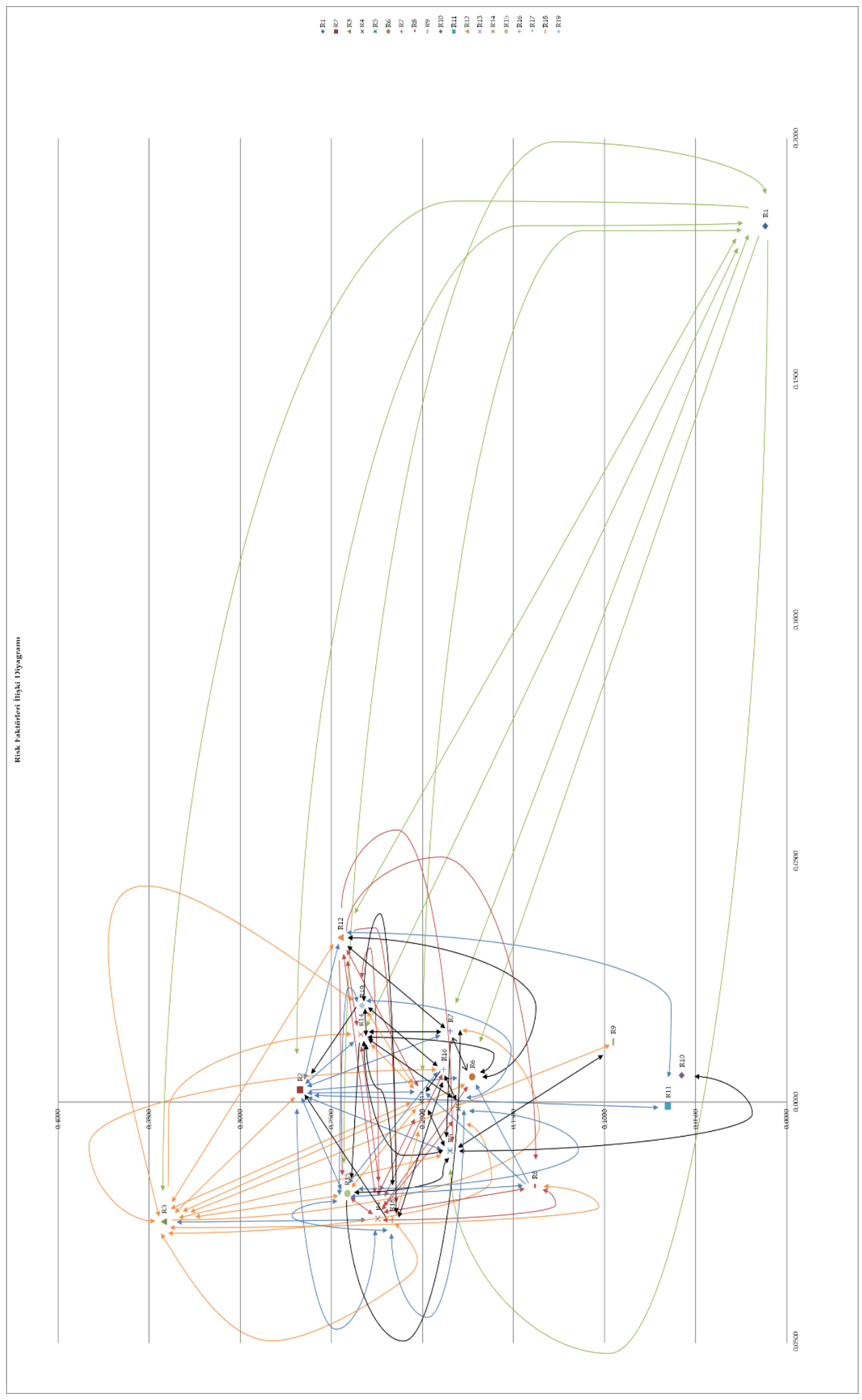


Tablo 7: YLL Üzerinde Etkili Olan Risk Faktörlerinin Ağırlıkları

\begin{tabular}{|c|c|c|c|}
\hline $\begin{array}{c}\text { Risk } \\
\text { Faktörü } \\
\text { Kodu }\end{array}$ & $\begin{array}{c}\text { Risk Faktörü } \\
\text { Adı }\end{array}$ & $\begin{array}{l}\text { Ağırlık } \\
(\%)\end{array}$ & $\begin{array}{c}\text { Risk Faktörü } \\
\text { Etki Türü* }\end{array}$ \\
\hline$R_{1}$ & Beslenmeyle İlgili Riskler & 9,35 & Etkileyen \\
\hline$R_{2}$ & Alkol Kullanımı & 7,29 & Etkileyen \\
\hline$R_{3}$ & Madde Kullanımı & 6,75 & Etkilenen \\
\hline$R_{4}$ & Yetersiz Fiziksel Aktivite & 6,60 & Etkilenen \\
\hline$R_{5}$ & $\begin{array}{l}\text { Tütün Kullanımı (Aktif ve Pa- } \\
\text { sif) }\end{array}$ & 6,39 & Etkilenen \\
\hline$R_{6}$ & Yüksek Beden Kitle İndeksi & 6,39 & Etkileyen \\
\hline$R_{7}$ & Böbrek Fonksiyon Bozukluğu & 6,16 & Etkileyen \\
\hline$R_{8}$ & Yüksek Sistolik Kan Basıncı & 5,95 & Etkilenen \\
\hline$R_{9}$ & Mesleki Riskler & 5,47 & Etkileyen \\
\hline$R_{10}$ & Yüksek Açlık Kan Şekeri & 5,14 & Etkileyen \\
\hline$R_{11}$ & $\begin{array}{l}\text { Çocuklukta Kötü Muameleye } \\
\text { Maruz Kalma }\end{array}$ & 5,06 & Etkilenen \\
\hline$R_{12}$ & Çevreyle İlgili Diğer Riskler & 5,05 & Etkileyen \\
\hline$R_{13}$ & Aile İçi Şiddet & 4,97 & Etkilenen \\
\hline$R_{14}$ & Yüksek LDL Kolesterol & 4,92 & Etkileyen \\
\hline$R_{15}$ & $\begin{array}{l}\text { Çocuk ve Annede } \\
\text { Malnütrisyon }\end{array}$ & 4,71 & Etkilenen \\
\hline$R_{16}$ & $\begin{array}{l}\text { Düşük Kemik Mineral Yoğun- } \\
\text { luğu }\end{array}$ & 3,81 & Etkileyen \\
\hline$R_{17}$ & $\begin{array}{l}\text { Güvenli Olmayan Su, Sanitas- } \\
\text { yon, El Yıkama }\end{array}$ & 2,62 & Etkilenen \\
\hline$R_{18}$ & Korunmasız Cinsel İlişki & 1,78 & Etkilenen \\
\hline$R_{19}$ & Hava Kirliliği & 1,58 & Etkileyen \\
\hline
\end{tabular}

*Risk Faktörünün Etki Türü: Risk faktörünün diğer risk faktörleri üzerindeki etkisini ifade etmektedir. Risk faktörü etki türü “etkileyen” ise diğer faktörleri etkilediğini; aksi takdirde etkilediği göstermektedir.

Yapılan analiz neticesinde elde edilen bulgulara göre; $R_{2}$ (alkol kullanımı), $R_{12}$ (madde kullanımı), $R_{14}$ (tütün kullanımı), $\mathrm{R}_{19}$ (yüksek beden kitle indeksi), $R_{16}$ (yüksek açlık kan şekeri), $R_{7}$ (çocuklukta kötü muameleye maruz kalma), $R_{1}$ (aile içi şiddet), $R_{6}$ (çocuk ve annede malnütrisyon), $R_{9}$ (güvenli olmayan su, sanitasyon ve el ylkama) ve $R_{10}$ (hava kirliliği) risk faktörleri etkileyen yani neden sinıfında yer alan risk faktörleri iken; $R_{3}$ (beslenmeyle ilgili riskler), $R_{15}$ (yetersiz fiziksel aktivite), $R_{4}$ (böbrek fonksiyon bozukluğu), $R_{18}$ (yüksek sistolik kan basıncı), $R_{13}$ (mesleki riskler), $R_{5}$ (çevreyle ilgili diğer riskler), $R_{17}$ (yüksek LDL kolesterol), $R_{8}$ (düşük kemik mineral yoğunluğu) 
ve $R_{11}$ (korumasız cinsel ilişki) risk faktörleri etkilenen; yani, sonuç grubunda yer alan faktörlerdir. Bununla birlikte bir risk faktörünün net etkileyen sınıfında yer alan bir faktör olması, söz konusu faktörün diğer faktörlerden etkilenmediği anlamına gelmemektedir. Benzer şekilde herhangi bir risk faktörünün net etkilenen faktör olması, diğer risk faktörlerini etkilemeyeceği anlamına da gelmemektedir. Net etkileyen ya da etkilenen olma durumu, bir risk faktörünün Eşitlik (6)'da gösterilen $K_{i}$ ve Eşitlik (7)'de gösterilen $N_{i}$ değerleri arasındaki farkın; yani $\left(K_{i}-N_{i}\right)$ değerinin pozitif ya da negatif olmasına göre değişmektedir. Bir diğer ifadeyle herhangi bir risk faktörünün diğer risk faktörlerini etkileme derecesi, diğer risk faktörlerinden etkilenme derecesinden daha büyük ise söz konusu risk faktörü net etkileyen; aksi durumda net etkilenen risk faktörü olmaktadır.

$\mathrm{Bu}$ bağlamda $R_{1}$ (aile içi şiddet) net etkileyen bir risk faktörü olarak; $R_{2}$ (alkol kullanımı), $R_{3}$ (beslenmeyle ilgili riskler), $R_{5}$ (çevreyle ilgili diğer riskler), $R_{6}$ (çocuk ve annede malnütrisyon), $R_{7}$ (çocuklukta kötü muameleye maruz kalma), $R_{12}$ (madde kullanımı), $R_{13}$ (mesleki riskler), $R_{14}$ (tütün kullanımı) ve $R_{15}$ (yetersiz fiziksel aktivite) risk faktörlerini etkilerken; $R_{2}$ (alkol kullanımı), $R_{7}$ (çocuklukta kötü muameleye maruz kalma), $R_{12}$ (madde kullanımı), $R_{13}$ (mesleki riskler), $R_{14}$ (tütün kullanımı) risk faktörlerinden de etkilenmektedir.

$R_{2}$ (alkol kullanımı) net etkileyen risk faktörü olarak; $R_{1}$ (aile içi şiddet), $R_{3}$ (beslenmeyle ilgili riskler), $R_{4}$ (böbrek fonksiyon bozukluğu), $R_{5}$ (çevreyle ilgili diğer riskler), $R_{6}$ (çocuk ve annede malnütrisyon), $R_{7}$ (çocuklukta kötü muameleye maruz kal$\mathrm{ma}$ ), $R_{11}$ (korunmasız cinsel ilişki), $R_{12}$ (madde kullanımı), $R_{13}$ (mesleki riskler), $R_{14}$ (tütün kullanımı), $R_{15}$ (yetersiz fiziksel aktivite), $R_{18}$ (yüksek sistolik kan basıncı) ve $R_{19}$ (yüksek beden kitle indeksi) risk faktörlerini etkilerken; $R_{1}$ (aile içi şiddet), $R_{3}$ (beslenmeyle ilgili riskler), $R_{4}$ (böbrek fonksiyon bozukluğu), $R_{5}$ (çevreyle ilgili diğer riskler), $R_{7}$ (çocuklukta kötü muameleye maruz kalma), $R_{11}$ (korunmasız cinsel ilişki), $R_{12}$ (madde kullanımı), $R_{13}$ (mesleki riskler), $R_{15}$ (yetersiz fiziksel aktivite), $R_{18}$ (yüksek sistolik kan basıncı) ve $R_{19}$ (yüksek beden kitle indeksi) risk faktörlerinden de etkilenmektedir.

$R_{3}$ (beslenmeyle ilgili riskler) net etkilenen risk faktörü olarak; $R_{1}$ (aile içi şiddet), $R_{2}$ (alkol kullanımı), $R_{4}$ (böbrek fonksiyon bozukluğu), $R_{5}$ (çevreyle ilgili diğer riskler), $R_{6}$ (çocuk ve annede malnütrisyon), $R_{8}$ (düşük kemik mineral yoğunluğu), $R_{9}$ (güvenli olmayan su, sanitasyon ve el yıkama), $R_{12}$ (madde kullanımı), $R_{13}$ (mesleki riskler), $R_{15}$ (yetersiz fiziksel aktivite), $R_{16}$ (yüksek açlık kan şekeri), $R_{17}$ (yüksek LDL kolesterol), $R_{18}$ (yüksek sistolik kan basıncı) ve $R_{19}$ (yüksek beden kitle indeksi) risk faktörlerinden etkilenirken; $R_{2}$ (alkol kullanımı), $R_{4}$ (böbrek fonksiyon bozukluğu), $R_{5}$ (çevreyle ilgili diğer riskler), $R_{6}$ (çocuk ve annede malnütrisyon), $R_{7}$ (çocuklukta kötü muameleye maruz kalma), $R_{8}$ (düşük kemik mineral yoğunluğu), $R_{9}$ (güvenli olmayan su, sanitasyon ve el yıkama), $R_{12}$ (madde kullanımı), $R_{13}$ (mesleki riskler), $R_{14}$ (tütün kullanımı), $R_{15}$ (yetersiz fiziksel aktivite), $R_{16}$ (yüksek açlık kan şekeri), $R_{17}$ (yüksek LDL kolesterol), $R_{18}$ (yüksek sistolik kan basıncı) ve $R_{19}$ (yüksek beden kitle indeksi) risk faktörlerini de etkilemektedir. 
$R_{4}$ (böbrek fonksiyon bozukluğu) net etkilenen risk faktörü olarak; $R_{2}$ (alkol kullanımı), $R_{3}$ (beslenmeyle ilgili riskler), $R_{6}$ (çocuk ve annede malnütrisyon), $R_{8}$ (düşük kemik mineral yoğunluğu), $R_{12}$ (madde kullanımı), $R_{13}$ (mesleki riskler), $R_{14}$ (tütün kullanımı), $R_{15}$ (yetersiz fiziksel aktivite), $R_{16}$ (yüksek açlık kan şekeri), $R_{17}$ (yüksek LDL kolesterol), $R_{18}$ (yüksek sistolik kan basıncı), $R_{19}$ (yüksek beden kitle indeksi) risk faktörlerinden etkilenirken; $R_{2}$ (alkol kullanımı), $R_{3}$ (beslenmeyle ilgili riskler), $R_{6}$ (çocuk ve annede malnütrisyon), $R_{8}$ (düşük kemik mineral yoğunluğu), $R_{12}$ (madde kullanımı), $R_{13}$ (mesleki riskler), $R_{14}$ (tütün kullanımı), $R_{15}$ (yetersiz fiziksel aktivite), $R_{16}$ (yüksek açlık kan şekeri), $R_{17}$ (yüksek LDL kolesterol), $R_{18}$ (yüksek sistolik kan basınc1) ve $R_{19}$ (yüksek beden kitle indeksi) risk faktörlerini de etkilemektedir.

$R_{5}$ (çevreyle ilgili diğer riskler) net etkilenen risk faktörü olarak; $R_{1}$ (aile içi şiddet), $R_{2}$ (alkol kullanımı), $R_{3}$ (beslenmeyle ilgili riskler), $R_{7}$ (çocuklukta kötü muameleye maruz kalma), $R_{9}$ (güvenli olmayan su, sanitasyon ve el yıkama), $R_{10}$ (hava kirliliği), $R_{12}$ (madde kullanımı), $R_{13}$ (mesleki riskler) ve $R_{14}$ (tütün kullanımı) risk faktörlerinden etkilenirken; $R_{2}$ (alkol kullanımı), $R_{3}$ (beslenmeyle ilgili riskler), $R_{9}$ (güvenli olmayan su, sanitasyon ve el yıkama), $R_{10}$ (hava kirliliği), $R_{13}$ (mesleki riskler), $R_{14}$ (tütün kullanımı), $R_{15}$ (yetersiz fiziksel aktivite) risk faktörlerini de etkilemektedir.

$R_{6}$ (çocuk ve annede malnütrisyon) net etkileyen risk faktörü olarak; $R_{3}$ (beslenmeyle ilgili riskler), $R_{4}$ (böbrek fonksiyon bozukluğu), $R_{7}$ (çocuklukta kötü muameleye maruz kalma), $R_{11}$ (korunmasız cinsel ilişki) ve $R_{14}$ (tütün kullanımı) risk faktörlerini etkilerken; $R_{1}$ (aile içi şiddet), $R_{2}$ (alkol kullanımı), $R_{3}$ (beslenmeyle ilgili riskler), $R_{4}$ (böbrek fonksiyon bozukluğu), $R_{7}$ (çocuklukta kötü muameleye maruz kalma), $R_{8}$ (düşük kemik mineral yoğunluğu), $R_{12}$ (madde kullanımı) ve $R_{14}$ (tütün kullanımı) risk faktörlerinden de etkilenmektedir.

$R_{7}$ (çocuklukta kötü muameleye maruz kalma) net etkileyen risk faktörü olarak; $R_{1}$ (aile içi şiddet), $R_{2}$ (alkol kullanımı), $R_{5}$ (çevreyle ilgili diğer riskler), $R_{6}$ (çocuk ve annede malnütrisyon), $R_{12}$ (madde kullanımı), $R_{14}$ (tütün kullanımı) ve $R_{15}$ (yetersiz fiziksel aktivite) risk faktörlerini etkilerken; $R_{1}$ (aile içi şiddet), $R_{2}$ (alkol kullanımı), $R_{3}$ (beslenmeyle ilgili riskler), $R_{6}$ (çocuk ve annede malnütrisyon), $R_{12}$ (madde kulla$\mathrm{nımı}$ ), $R_{14}$ (tütün kullanımı) risk faktörlerinden de etkilenmektedir.

$R_{8}$ (düşük kemik mineral yoğunluğu) net etkilenen risk faktörü olarak; $R_{3}$ (beslenmeyle ilgili riskler), $R_{4}$ (böbrek fonksiyon bozukluğu), $R_{12}$ (madde kullanımı) ve $R_{15}$ (yetersiz fiziksel aktivite) risk faktörlerinden etkilenirken; $R_{3}$ (beslenmeyle ilgili riskler), $R_{4}$ (böbrek fonksiyon bozukluğu), $R_{6}$ (çocuk ve annede malnütrisyon), $R_{13}$ (mesleki riskler) ve $R_{15}$ (yetersiz fiziksel aktivite) risk faktörlerini de etkilemektedir.

$R_{9}$ (güvenli olmayan su, sanitasyon ve el yıkama) net etkileyen risk faktörü olarak; $R_{3}$ (beslenmeyle ilgili riskler) ve $R_{4}$ (böbrek fonksiyon bozukluğu) risk faktörlerini etkilerken; $R_{3}$ (beslenmeyle ilgili riskler) ve $R_{5}$ (çevreyle ilgili diğer riskler) risk faktörlerinden de etkilenmektedir.

$R_{10}$ (hava kirliliği) net etkileyen risk faktörü olarak; sadece $R_{5}$ (çevreyle ilgili diğer riskler) risk faktörünü etkilerken; yine sadece $R_{5}$ (çevreyle ilgili diğer riskler) risk 
faktöründen etkilenmektedir. Bu iki risk faktörü karşılıklı olarak birbirlerini etkilemekte ve birbirlerinden etkilenmektedirler. $R_{10}$ (düşük kemik mineral yoğunluğu)'nun $R_{5}$ (çevreyle ilgili diğer riskler)'i etkileme derecesi $R_{5}$ (çevreyle ilgili diğer riskler)'den etkilenme derecesinden daha büyük olduğundan $R_{10}$ (hava kirliliği) net etkileyen risk faktörü olmuştur.

$R_{11}$ (korunmasız cinsel ilişki) net etkilenen risk faktörü olarak; $R_{2}$ (alkol kullanımı) ve $R_{12}$ (madde kullanımı) risk faktörlerinden etkilenirken; aynı zamanda, $R_{2}$ (alkol kullanımı) ve $R_{12}$ (madde kullanımı) risk faktörlerinden de etkilenmektedir.

$R_{12}$ (madde kullanımı) net etkileyen risk faktörü olarak; $R_{1}$ (aile içi şiddet), $R_{2}$ (alkol kullanımı), $R_{3}$ (beslenmeyle ilgili riskler), $R_{4}$ (böbrek fonksiyon bozukluğu), $R_{5}$ (çevreyle ilgili diğer riskler), $R_{6}$ (çocuk ve annede malnütrisyon), $R_{7}$ (çocuklukta kötü muameleye maruz kalma), $R_{8}$ (düşük kemik mineral yoğunluğu), $R_{11}$ (korunmasız cinsel ilişki), $R_{13}$ (mesleki riskler), $R_{14}$ (tütün kullanımı), $R_{15}$ (yetersiz fiziksel aktivite) ve $R_{18}$ (yüksek sistolik kan basıncı) risk faktörlerini etkilerken; $R_{1}$ (aile içi şiddet), $R_{2}$ (alkol kullanımı), $R_{3}$ (beslenmeyle ilgili riskler), $R_{4}$ (böbrek fonksiyon bozukluğu), $R_{6}$ (çocuk ve annede malnütrisyon), $R_{7}$ (çocuklukta kötü muameleye maruz kalma), $R_{11}$ (korunmasız cinsel ilişki) ve $R_{14}$ (tütün kullanımı) risk faktörlerinden de etkilenmektedir.

$R_{13}$ (mesleki riskler) net etkilenen risk faktörü olarak; $R_{1}$ (aile içi şiddet), $R_{2}$ (alkol kullanımı), $R_{3}$ (beslenmeyle ilgili riskler), $R_{4}$ (böbrek fonksiyon bozukluğu), $R_{5}$ (çevreyle ilgili diğger riskler), $R_{8}$ (düşük kemik mineral yoğunluğu), $R_{12}$ (madde kullanımı), $R_{14}$ (tütün kullanımı), $R_{15}$ (yetersiz fiziksel aktivite), $R_{16}$ (yüksek açlık kan şekeri), $R_{18}$ (yüksek sistolik kan basınc1) ve $R_{19}$ (yüksek beden kitle indeksi) risk faktörlerinden etkilenirken; $R_{1}$ (aile içi şiddet), $R_{2}$ (alkol kullanımı), $R_{3}$ (beslenmeyle ilgili riskler), $R_{4}$ (böbrek fonksiyon bozukluğu), $R_{5}$ (çevreyle ilgili diğer riskler), $R_{14}$ (tütün kullanımı), $R_{15}$ (yetersiz fiziksel aktivite), $R_{18}$ (yüksek sistolik kan basıncı) ve $R_{19}$ (yüksek beden kitle indeksi) risk faktörlerini de etkilemektedir.

$R_{14}$ (tütün kullanımı) net etkileyen risk faktörü olarak; $R_{1}$ (aile içi şiddet), $R_{4}$ (böbrek fonksiyon bozukluğu), $R_{5}$ (çevreyle ilgili diğer riskler), $R_{6}$ (çocuk ve annede malnütrisyon), $R_{7}$ (çocuklukta kötü muameleye maruz kalma), $R_{12}$ (madde kullanımı), $R_{13}$ (mesleki riskler), $R_{15}$ (yetersiz fiziksel aktivite), $R_{17}$ (yüksek LDL kolesterol), $R_{18}$ (yüksek sistolik kan basincı), $R_{19}$ (yüksek beden kitle indeksi) risk faktörlerini etkilerken; $R_{1}$ (aile içi şiddet), $R_{2}$ (alkol kullanımı), $R_{3}$ (beslenmeyle ilgili riskler), $R_{4}$ (böbrek fonksiyon bozukluğu), $R_{5}$ (çevreyle ilgili diğer riskler), $R_{6}$ (çocuk ve annede malnütrisyon), $R_{7}$ (çocuklukta kötü muameleye maruz kalma), $R_{12}$ (madde kullanımı), $R_{13}$ (mesleki riskler), $R_{17}$ (yüksek LDL kolesterol) ve $R_{18}$ (yüksek sistolik kan basıncı) risk faktörlerinden de etkilenmektedir.

$R_{15}$ (yetersiz fiziksel aktivite) net etkilenen risk faktörü olarak; $R_{1}$ (aile içi şiddet), $R_{2}$ (alkol kullanımı), $R_{3}$ (beslenmeyle ilgili riskler), $R_{4}$ (böbrek fonksiyon bozuklu$\breve{g u}$ ), $R_{5}$ (çevreyle ilgili diğer riskler), $R_{7}$ (çocuklukta kötü muameleye maruz kalma), $R_{8}$ (düşük kemik mineral yoğunluğu), $R_{12}$ (madde kullanımı), $R_{13}$ (mesleki riskler), $R_{14}$ (tütün kullanımı), $R_{16}$ (yüksek açlık kan şekeri), $R_{17}$ (yüksek LDL kolesterol), $R_{18}$ 
(yüksek sistolik kan basınc1), $R_{19}$ (yüksek beden kitle indeksi) risk faktörlerinden etkilenirken; $R_{2}$ (alkol kullanımı), $R_{3}$ (beslenmeyle ilgili riskler), $R_{4}$ (böbrek fonksiyon bozukluğu), $R_{8}$ (düşük kemik mineral yoğunluğu), $R_{13}$ (mesleki riskler), $R_{16}$ (yüksek açlık kan şekeri), $R_{17}$ (yüksek LDL kolesterol), $R_{18}$ (yüksek sistolik kan basıncı) ve $R_{19}$ (yüksek beden kitle indeksi) risk faktörlerinden de etkilenmektedir.

$R_{16}$ (yüksek açlık kan şekeri) net etkileyen risk faktörü olarak; $R_{3}$ (beslenmeyle ilgili riskler), $R_{4}$ (böbrek fonksiyon bozukluğu), $R_{13}$ (mesleki riskler), $R_{15}$ (yetersiz fiziksel aktivite), $R_{17}$ (yüksek LDL kolesterol), $R_{18}$ (yüksek sistolik kan basinc1) ve $R_{19}$ (yüksek beden kitle indeksi) risk faktörlerini etkilerken; $R_{3}$ (beslenmeyle ilgili riskler), $R_{4}$ (böbrek fonksiyon bozukluğu), $R_{15}$ (yetersiz fiziksel aktivite), $R_{17}$ (yüksek LDL kolesterol), $R_{18}$ (yüksek sistolik kan basıncı) ve $\mathrm{R}_{19}$ (yüksek beden kitle indeksi) risk faktörlerinden de etkilenmektedir.

$R_{17}$ (yüksek LDL kolesterol) net etkilenen risk faktörü olarak; $R_{3}$ (beslenmeyle ilgili riskler), $R_{4}$ (böbrek fonksiyon bozukluğu), $R_{14}$ (tütün kullanımı), $R_{15}$ (yetersiz fiziksel aktivite), $R_{16}$ (yüksek açlık kan şekeri), $R_{18}$ (yüksek sistolik kan basınc1) ve $R_{19}$ (yüksek beden kitle indeksi) risk faktörlerinden etkilenirken; aynı zamanda, $R_{3}$ (beslenmeyle ilgili riskler), $R_{4}$ (böbrek fonksiyon bozukluğu), $R_{14}$ (tütün kullanımı), $R_{15}$ (yetersiz fiziksel aktivite), $R_{16}$ (yüksek açlık kan şekeri), $R_{18}$ (yüksek sistolik kan basıncı) ve $R_{19}$ (yüksek beden kitle indeksi) risk faktörlerini de etkilemektedir.

$R_{18}$ (yüksek sistolik kan basıncı) net etkilenen risk faktörü olarak; $R_{2}$ (alkol kullanımı), $R_{3}$ (beslenmeyle ilgili riskler), $R_{4}$ (böbrek fonksiyon bozukluğu), $R_{12}$ (madde kullanımı), $R_{13}$ (mesleki riskler), $R_{14}$ (tütün kullanımı), $R_{16}$ (yüksek açılık kan şekeri), $R_{17}$ (yüksek LDL kolesterol) ve $R_{19}$ (yüksek beden kitle indeksi) risk faktörlerinden etkilenirken; $R_{2}$ (alkol kullanımı), $R_{3}$ (beslenmeyle ilgili riskler), $R_{4}$ (böbrek fonksiyon bozukluğu), $R_{13}$ (mesleki riskler), $R_{14}$ (tütün kullanımı), $R_{15}$ (yetersiz fiziksel aktivite), $R_{16}$ (yüksek açlık kan şekeri), $R_{17}$ (yüksek LDL kolesterol) ve $R_{19}$ (yüksek beden kitle indeksi) risk faktörlerinden de etkilenmektedir.

$R_{19}$ (yüksek beden kitle indeksi) net etkileyen risk faktörü olarak; $R_{2}$ (alkol kullanımı), $R_{3}$ (beslenmeyle ilgili riskler), $R_{4}$ (böbrek fonksiyon bozukluğu), $R_{13}$ (mesleki riskler), $R_{16}$ (yüksek açlık kan şekeri), $R_{17}$ (yüksek LDL kolesterol) ve $\mathrm{R}_{18}$ (yüksek sistolik kan basınc1) risk faktörlerini etkilerken; $R_{2}$ (alkol kullanımı), $R_{3}$ (beslenmeyle ilgili riskler), $R_{4}$ (böbrek fonksiyon bozukluğu), $R_{13}$ (mesleki riskler), $R_{14}$ (tütün kullanımı), $R_{15}$ (yetersiz fiziksel aktivite), $R_{16}$ (yüksek açlık kan şekeri), $R_{17}$ (yüksek LDL kolesterol) ve $R_{18}$ (yüksek sistolik kan basıncı) risk faktörlerinden de etkilenmektedir.

Yapılan analizle faktörler arası içsel ilişkiler, etkileyen ve etkilenen faktörler belirlendiği gibi; söz konusu faktörlerin ağırlıkları de hesaplanmıştır. Hesaplanan bu ağırlıklar Tablo 7'de gösterilmiştir. Buna göre net etkileyen faktörler arasında \%7,29'luk ağırlıkla alkol kullanımı ilk sırada yer almaktadır. Bu net etkileyen risk faktörünü sırasıyla; \%6,75'lik ağılıkla madde kullanımı, \%6,39'luk ağırlıkla tütün kullanımı, \%6,39'luk ağırlıkla yüksek beden kitle indeksi, \%5,14'lük ağırlıkla yüksek açlık kan şekeri, \%5,06'llk ağırlıkla çocuklukta kötü muameleye maruz kalma, \%4,97'lik ağırlıkla aile içi şiddet, \%4,71'lik ağırlıkla çocuk ve annede malnütrisyon, 
\%2,62'lik ağırlıkla güvenli olmayan su, sanitasyon ve el yıkama ve son olarak \%1,58'lik ağırlıkla hava kirliliği net etkileyen risk faktörleri takip etmektedir. Net etkilenen faktörler arasında ise, \%9,35'lik ağırlıkla beslenmeyle ilgili riskler ilk sırada yer alırken söz konusu bu net etkilenen risk faktörünü sırasıyla; \%6,60'lık ağırlıkla yetersiz fiziksel aktivite, \%6,16'llk ağırlıkla böbrek fonksiyon bozukluğu, \%5,95'lik ağırlıkla yüksek sistolik kan basıncı, \%5,47'lik ağırlıkla mesleki riskler, \%5,05'lik ağırlıkla çevreyle ilgili diğer riskler, \%4,92'lik ağırlıkla yüksek LDL kolesterol, \%3,81'lik ağırlıkla düşük kemik mineral yoğunluğu ve nihayetinde \%1,78'lik ağırlıkla korumasız cinsel ilişki izlemektedir.

\section{Sonuç ve Öneriler}

Kanuni Sultan Süleyman Han’ın "Halk içinde muteber bir nesne yok devlet gibi, Olmaya devlet cihanda, bir nefes sihhat gibi” sözleri sağlığın ne denli önemli olduğunu anlatmaya yeter bir ifadedir. $\mathrm{Bu}$ öneme binaen tezahür eden bu çalışmada, bireylerin sağlıklı geçirdikleri yaşam yıllarındaki kaybı ifade eden YLL ölçütü üzerinde etkili olan başlıca 19 risk faktörünün içsel ilişkileri belirlenmeye ve söz konusu faktörlerin ağırlıkları hesaplanmaya çalışılmıştır. Bu amaç doğrultusunda kullanılan DEMATEL yöntemi, analiz edilen 19 risk faktörünü; 10 tanesini etkileyen, 9 tanesini de etkilenen olmak üzere iki gruba ayırmıştır. Yöntem bu yolla, kıt olan kaynakları tüm risk faktörlerinin çözümüne tahsis etmek yerine, esas çabanın ilk olarak YLL üzerinde daha etkili olduğu anlaşılan 10 etkileyen risk faktörüne yönlendirilmesi için bir firsat sunmuştur. Bu fırsat iyi değerlendirilmek suretiyle, YLL'de meydana gelebilecek herhangi bir kaybı ortadan kaldırmaya yönelik hayata geçirilecek çabaların da etkililiği arttırılabilecektir.

Analizle elde edilen bulgular; etkileyen yani neden grubunda yer alan risk faktörlerinin, ağırlıklarına göre; alkol kullanımı, madde kullanımı, tütün kullanımı, yüksek beden kitle indeksi, yüksek açlık kan şekeri, çocuklukta kötü muameleye maruz kalma, aile içi şiddet, çocuk ve annede malnütrisyon, güvenli olmayan su, sanitasyon ve el yıkama ve hava kirliliği şeklinde sıralandığını göstermektedir. Söz konusu bu faktörlerin pek çoğunun, nispeten yüksek açlık kan şekeri hariç, koruyucu sağlık uygulamaları, küçük yaşta başlayan eğitim faaliyetleri, bilinçlendirme ve farkındalık yaratmaya yönelik kampanyalar, bağımlılık yaratıcı maddelerin kullanımını azaltmaya, ortadan kaldırmaya veyahut bu tür zararlı maddelere başlama yaşını yükseltmeye yönelik uygulamaya konulacak yasal düzenlemeler, sosyal ve kültürel etkinlikler, sportif faaliyetlerin toplum geneline yayılmasını sağlayacak organizasyonlar vasıtasıyla ortaya çıkma olasılıkları düşürülebilecektir. Hemen belirtmek gerekir ki; elde edilen bu bulgular, etkileyen risk faktörleri tamamen ortadan kaldırılsa dahi etkilenen risk faktörlerinin ve/veya sağlıklı geçirilecek yaşam yılında meydana gelecek kayıpların ortaya çıkmaması anlamına gelmemektedir. Zira, bu faktörler sadece ve sadece risk faktörleridir. Kaldı ki; pek çok etkileyen ve etkilenen risk faktörü arasında karşlıklı bir etkileşim olduğu anlaşılmaktadır. Etkileyen faktörlerin ağırlıkları incelendiğinde bağımlılık yapıcı madde kullanımının ilk üç sırada yer aldığı anlaşılmaktadır. Söz konusu bu maddeleri kullanmaya başlama yaşının giderek düşmesi birey ve toplum sağlığı açısından ciddi bir risk 
oluşturmaktadır. Son yıllarda tütün ve tütün mamullerinin kullanımını azaltmaya yönelik uygulamaya konulan sağlı politikaları ve idari politikalar, tütün ve tütün kullanımında dikkate değer bir düşüşe neden olmuştur. Aynı zamanda, tütün ve tütün mamullerinin kullanılabileceği alanların giderek kısıtlanması pasif içicilik nedeniyle maruz kalınan risklerin de azaltılmasına olumlu katkı yapmıştır. Tütün ve tütün mamullerinin tutundurulmasına, özendirilmesine, satılmasina ve kullanılmasına yönelik hayata geçirilen tedbirlerin alkol kullanımına yönelik de uygulamaya konması YLL'de meydana gelebilecek kayıpların ortaya çıkma riskini düşürecektir. Madde kullanımını önlemeye yönelik farkındalık yaratacak faaliyetlerin yanı sıra, güvenlik tedbirlerinin arttırılması, bu tür maddeleri satanlara ve özendirenlere yönelik daha ağır cezai müeyyidelerin getirilmesi de daha sağlıklı bir nesil için elzem bir konudur. Elbette ki; uyuşturucu madde kullanımı hariç olmak üzere, tütün ve alkol gibi bağımlılığa neden olan maddelerin kullanımını kısıtlamaya yönelik hayata geçirilecek tedbirlerin bireysel hak ve özgürlükler göz önüne alınarak uygulamaya konması da bu tedbirlerin toplum geneline yayılması ve benimsenmesi bakımından kolaylaştırıcı bir rol üstlenecektir.

Son olarak, analizle ulaşılan bulguların doğru yorumlanabilmesi için araştırmanın sınırlılıklarının dikkate alınması gerekliliği unutulmamalıdır. Keza, kullanılan DEMATEL yöntemi uzman görüşüne dayanan bir yöntemdir. Her ne kadar görüşleri alınan katılımcılar alanlarında uzman dahi olsalar, bu durum sonuçlar üzerindeki öznelliği ortadan kaldırmamaktadır. Bir başka ifadeyle, karar verici kitlesinin değişmesi durumunda risk faktörleri arasındaki ilişki ağının ve faktör ağılıklarının değişmesi kaçınılmazdır. Bu nedenle bundan sonraki süreçte konuyla ilgili olarak yapılacak çalışmalarda daha geniş bir katılımcı kitlesinin sağlanması sonuçlar üzerinde uzlaşı sağlanmasını da kolaylaştıracaktır. Aynı zamanda, sadece YLL üzerinde etkili olan risk faktörlerinin değil; YLL ve YLD üzerinde etkili olan tüm risk faktörlerinin bir arada ele alınacağı bir başka araştırma yoluyla DALY ölçütü üzerinde etkili olan risk faktörleri sınıflandırılarak literatüre katkı sağlanabilir. Bunun yanı sıra, bu çalışmada karar vericilerin bireysel değerlendirmeleri için dörtlü bir skala kullanılmıştır. Bunun karar vericilerin değerlendirmelerini kısıtlayıcı bir husus olabileceği gözden kaçırılmamalıdır. Bu tarz bir kısıtlamayı ortadan kaldırabilmek adına, gelecekte yapılacak çalışmalarda bulanık küme teorisinin ve bulanık sayıların, üçgen ya da yamuk gibi, kullanılması; bunun da ötesinde kullanımı henüz çok yaygın olmasa da tip-2 bulanık sayıların araştırmalarda denenmesi karar vericilere değerlendirme ve yargılarını ifade ederken daha geniş bir yelpazede yer alan dilsel değişkenleri kullanabilme imkanı sunacaktır. 


\section{Kaynakça}

Aktaş, Ramazan, Mete M. Doğanay, Yunus Gökmen, Yavuz Gazibey ve Ufuk Türen. Sayısal Karar Verme Yöntemleri. İstanbul: Beta Yayınları, 2015.

Arslan, Deniz Tugay ve İsmail Ağırbaş. "Sağlık Çıktılarının Ölçülmesi: QALY ve DALY”. Sağlikta Performans ve Kalite Dergisi. 13 (2017): 99-126.

Bahadori, Mohammadkarim ve Ramin Ravangard. "Analysis of the Systematic Relationships among Social Determinants of Health (SDH) and Identification of Their Prioritization in Iran Using DEMATEL Technique". Iranian Journal of Public Health. 42/12 (2013): 1457-1464.

Bahadori, Mohammadkarim, Mahmood Salesi, Ramin Ravangard, Seyed Mojtaba Hosseini, Mehdi Raadabadi, Amin Hojati Dana ve Ahmad Ameryoun. "Prioritization of Factors Affecting Time Management among Health Managers". International Journal of Travel Medicine and Global Health. 3/4 (2015): 159-164.

Bulut, Sinan. "Sağlıkta Sosyal Bir Belirleyici; Fiziksel Aktivite". Turkish Bulletin of Hygiene and Experimental Biology/Türk Hijyen ve Deneysel Biyoloji. 70/4 (2013): 205-215.

Büyüközkan, Gülçin ve Sezin Güleryüz. “An Integrated DEMATEL-ANP Approach for Renewable Energy Resources Selection in Turkey". International Journal of Production Economics. 182 (2016): 435-448.

Candan, Gökçe. "İlaç Sektöründe Başarılı Tersine Lojistik Uygulamaları İçin Faktörlerin Değerlendirilmesi: Bulanık Mantık Temelli Yaklaşım. İşletme Araştırmaları Dergisi”. Journal of Business Research Turk. 10/3 (2018): 592-605.

Chang, Dong-Shang, Shu-Ming Liu ve Yi-Chun Chen. "Applying DEMATEL to Assess TRIZ's Inventive Principles for Resolving Contradictions in the Long-Term Care Cloud System". Industrial Management and Data Systems. 117/6 (2017): 1244-1262.

Chen, Xiujuan, Guangqian Qiu, Linhai Wu, Guoyan Xu, Jianhua Wang ve Wuyang $\mathrm{Hu}$. "Influential Impacts of Combined Government Policies for Safe Disposal of Dead Pigs on Farmer Behavior". Environmental Science and Pollution Research. 24 (2017): 3997-4007.

Çımrın, Arif, Peri Arbak, İbrahim Akkurt, Emel Ceylan, Fatma Evyapan, Ayten Filiz ve Abdurrahman Şenyiğit. Ed., Muzaffer Metintaş. "Çevresel-Mesleksel Akciğer Hastalıkları", Türkiyede Temel Akciğer Sağlığı Sorunları ve Çözüm Önerileri. Ankara: Sentez Matbaacılık ve Yayıncılık, 2010.

Dikmen, Feyyaz Cengiz ve Yunus Taş. “Applying Dematel Approach to Determine Factors Affecting Hospital Service Quality in A University Hospital: A Case Study”. Yönetim Bilimleri Dergisi/Journal of Administrative Sciences. 16/2 (2018): 11-28.

Elbir, Tolga, Abdurrahman Bayram, Melik Kara, Hasan Altıo, Remzi Seyfioğlu, Pınar Ergün ve Sedef Şimşir. "İzmir Kent Merkezinde Karayolu Trafiğinden Kaynaklanan Hava Kirliliğinin İncelenmesi”. Dokuz Eylül Üniversitesi Mühendislik Fakültesi Fen ve Mühendislik Dergisi. 12/1 (2010): 1-17. 
Frichi, Youness, Fouad Jawab ve Said Boutahari. “The Mixed-Method 5W2D Approach for Health System Stakeholders Analysis in Quality of Care: An Application to the Moroccan Context". Int. J. Environ. Res. Public Health. 16/2899 (2019): $1-25$.

George-Ufot, Glory, Ying Ou ve Ifeyinwa Juliet Orji. "Sustainable Lifestyle Factors Influencing Industries' Electric Consumption Patterns Using Fuzzy Logic and DEMATEL: The Nigerian Perspective". Journal of Cleaner Production. 162 (2017): 624-637.

Guigoz, Yves. "The Mini Nutritional Assessment review of the literature - What does it tell us?". The Journal of Nutrition, Health and Aging. 10 (2006): 466-487.

Hinduja, Akshay ve Manju Pandey. "Assessment of Healthcare Waste Treatment Alternatives Using an Integrated Decision Support Framework". International Journal of Computational Intelligence Systems. 12/1 (2019): 318-333.

Guy, Hutton ve Haller Laurence. Evaluation of the Costs and Benefits of Water and Sanitation Improvements at the Global Level. Geneva: World Health Organization, 2004.

Okan İbiloğlu, Aslıhan. “Aile İçi Şiddet“. Psikiyatride Güncel Yaklaşımlar. 4/2 (2012): 204-222.

Karlıkaya, Celal, Funda Öztuna, Zeynep Aytemur Solak, Metin Özkan ve Osman Örsel. “Tütün Kontrolü”. Toraks dergisi. 7/1 (2006): 51-64.

Khan, Muhammad Waseem, Yousaf Ali, Fabio De Felice, Aneel Salman ve Antonella Petrillo. "Impact of brick kilns industry on environment and human health in Pakistan". Science of the Total Environment. 678 (2019): 383-389.

Korkmaz Çetin, Saniye, Tezan BİLDİK, Serpil ERERMİş, Nagehan DEMİRAL, Burcu ÖZBARAN, Müge TAMAR ve Cahide AYDIN. "Erkek Ergenlerde Cinsel Davranış ve Cinsel Bilgi Kaynakları: Sekiz Yıl Arayla Değerlendirme”. Türk Psikiyatri Dergisi. 19/4 (2008): 390-397.

Kumar, Anil, Mohamad Amin Kaviani, Eleonora Bottani, Manoj Kumar Dash, Edmundas Kazimieras Zavadskas. "Investigating the Role of Social Media in Polio Prevention in India: A Delphi-DEMATEL Approach”. Kybernetes. 47/5 (2018): 1053-1072.

Liou, James.J.H., Ming-Tsang Lu, Shu-Kung Hu, Chia-Hua Cheng ve Yen-Ching Chuang. "A Hybrid MCDM Model for Improving the Electronic Health Record to Better Serve Client Needs". Sustainability. 9/1819 (2017): 1-13.

Liu, Hu-Chen, Jian-Xin You, Chao Lu, Yi-Zeng Chen. "Evaluating Health-care Waste Treatment Technologies Using a Hybrid Multi-criteria Decision Making Model”. Renewable and Sustainable Energy Reviews. 41 (2015): 932-942.

Liu, Yupeng, Yifei Chen ve Gwo-Hshiung Tzeng. "Identification of Key Factors in Consumers' Adoption Behavior of Intelligent Medical Terminals Based on a Hybrid Modified MADM Model for Product Improvement". International Journal of Medical Informatics. 105 (2017): 68-82.

Duncan, Mara, Jon Lane, Beth Scott ve David Trouba. Sanitation and health. PLoS medicine. 7/11 (2010): 1-6. 
Nilashi, Mehrbakhsh, Sarminah Samad, Azizah Abdul Manaf, Hossein Ahmadi, Tarik A. Rashid, Asmaa Munshi, Wafa Almukadi, Othman Ibrahim, Omed Hassan Ahmed. "Factors influencing medical tourism adoption in Malaysia: A DEMATEL Fuzzy TOPSIS approach". Computers and Industrial Engineering. 137/106005 (2019): 1-13.

Onat, Altan. “Türkiye'de Obezitenin Kardiyovasküler Hastalıklara Etkisi”. Türk Kardiyoloji Derneği Arşivi. 31/5 (2003): 279-289.

Ortiz Barrios, Miguel Angel, Zulmeira Herrera-Fontalvo, Javier Rúa-Muñoz and Saimon Ojeda-Gutiérrez, Fabio De Felice ve Antonella Petrillo. "An Integrated Approach to Evaluate the Risk of Adverse Events in Hospital Sector". Management Decision. 56/10 (2018): 2187-2224.

Örsal, Özlem. "Sağlık Yüksekokulu Öğrencilerinin Tütün ve Tütün Mamulleri Kullanma Alışkanlıkları Üzerine Kesitsel Bir Çalışma”. Turkish Journal of Research and Development in Nursing. 11/3 (2009):30-40.

Kaymak Özmen, Suna. "Aile içinde öfke ve saldırganlığın yansımaları". Ankara Üniversitesi Ĕ̆itim Bilimleri Fakültesi Dergisi. $37 / 2$ (2004): 27-39

Rehm, Jürgen, Jayadeep Patra ve Svetlana Popova. "Alcohol-attributable Mortality and Potential Years of Life Lost in Canada 2001: Implications for Prevention and Policy". Addiction. 101 (2006): 373-384.

Rehm, Jürgen, Robin Room, Kathryn Graham, Maristela Monteiro, Gerhard Gmel ve Christopher T. Sempos. “The Relationship of Average Volume of Alcohol Consumption and Patterns of Drinking to Burden of Disease". Addiction. 98 (2003): 1209-1228.

Shi, Xiaofeng, Jianying Li, Fei Wang, Hasan Dinçer ve Serhat Yüksel. "Hybrid Decision-Making Approach for the Service and Financial-Based Measurement of Universal Health Coverage for the E7 Economies". Int. J. Environ. Res. Public Health. 16/3295 (2019): 1-20.

Si, Sheng-Li, Xiao-Yue You, Hu-Chen Liu ve Jia Huang. "Identifying Key Performance Indicators for Holistic Hospital Management with a Modified DEMATEL Approach". Int. J. Environ. Res. Public Health. 14/934 (2017): 1-17.

Supeekit, Tuangyot, Tuanjai Somboonwiwat ve Duangpun Kritchanchai. "DEMATEL-modified ANP to evaluate internal hospital supply chain Performance". Computers and Industrial Engineering. 102 (2016): 318-330.

T.C. Sağlık Bakanlığı Temel Sağlık Hizmetleri Genel Müdürlüğü, Ulusal Ruh Săğl̆ğ Eylem Planı (2011-2023), Ankara: 2011.

T.C. Sağlık Bakanlığı, Sağlık İstatistikleri Yıllı̆̆ı, Ankara: Kuban Matbaacılık, 2017.

T.C. Sağlık Bakanlığı, Să̆lık İstatistikleri Yıllı̆̆ı 2018, Ankara: Kuban Matbaacılık, 2019.

Tezcan, Sabahat, Ayşegül Esin Ertan ve Dilek Aslan. "Beş Yaş Altı Çocuklarda Malnütrisyon Durumunun Değerlendirilmesi”. Türkiye Klinikleri Tip Bilimleri. 23/5 (2003): 420-429. 
Tsai, Wen-Hsien ve Wen-Chin Chou, "Selecting Management Systems for Sustainable Development in SMEs: A Novel Hybrid Model Based on DEMATEL, ANP, and ZOGP”, Expert Systems with Applications, 36 (2009): 1444-1458.

Ünal, Gülseren. "Aile İçi Şiddet". Aile ve Toplum Eğitim - Kültür ve Araştırma Dergisi. 2/7 (2005): 85-93.

"Cinsel Sağllk ve Üreme sağlığı”. Erişim 12 Aralık, 2019. https://www.who.int/reproductivehealth/curable-stis/en/.

"Hava Kirliliği”. Erişim 12 Aralık, 2019. https://www.who.int/airpollution/events/ expertconsult2019/en/.

"Health-topics/tobacco". Erişim 12 Aralık, 2019. https://www.who.int/health-topics/ tobacco.

“Obezite ve Aşırı Kilo”. Erişim 12 Aralık, 2019. https://www.who.int/en/news-room/ fact-sheets/detail/obesity-and-overweight.

"Sanitasyon". Erişim 12 Aralık, 2019. https://www.who.int/topics/sanitation/en/.

"Yetersiz Beslenme". Erişim 12 Aralık, 2019. https://www.who.int/topics/malnutrition/en/.

"Fiziksel Aktivite". Erişim 12 Aralık, 2019. https://www.who.int/health-topics/physical-activity. 


\title{
Investigation of the Risk Factos Affecting Years of Life Lost Via DEMATEL Method
}

\author{
AHMET SERHAT ULUDAĞ
}

\begin{abstract}
In this study, the causal relationship between the 19 risk factors that have an effect on the years of life lost (YLL) was investigated by DEMATEL method. The relative weights of these risk factors were calculated. In this way, it is aimed to ensure the effective use of scarce resources and the effectiveness of possible measures that can be implemented by eliminating the risks that may cause harm in healthy life year. According to the findings 19 risk factors; It was divided into two groups as 10 affecting and 9 affected. Among the influencing factors, the use of addictive substances, especially alcohol, has been identified as the risk factors affected and hence the most effective factors on years of life lost. The probability of occurrence of 10 risk factors in the affected group can be largely eliminated through awareness-raising, health and administrative measures and early education.
\end{abstract}

Keywords: Decision making, Decision making techniques, Public health, Life expectancy 